\title{
Cestode parasites (Neodermata, Platyhelminthes) from Malaysian birds, with description of five new species
}

\author{
Jean MARIAUX ${ }^{1, *} \&$ Boyko B. GEORGIEV ${ }^{2}$ \\ ${ }^{1}$ Natural History Museum of Geneva, CP 6434, 1211 Geneva 6, Switzerland. \\ ${ }^{2}$ Institute of Biodiversity and Ecosystem Research, Bulgarian Academy of Sciences, \\ 2 Gagarin Street, 1113 Sofia, Bulgaria. \\ *Corresponding author: jean.mariaux@ville-ge.ch \\ ${ }^{2}$ Email: bbg@ecolab.bas.bg \\ ${ }^{1}$ urn:1sid:zoobank.org:author:B97E611D-EC33-4858-A81C-3E656D0DA1E2 \\ ${ }^{2}$ urn:1sid:zoobank.org:author:88352C92-555A-444D-93F4-97F9A3AC2AEF
}

\begin{abstract}
We studied the cestode fauna (Platyhelminthes) of forest birds in Malaysia (Selangor) collected during a field trip in 2010. Ninety birds of 37 species were examined and global prevalence of cestodes was $15.3 \%$. Five new taxa are described: Emberizotaenia aeschlii sp. nov. (Dilepididae) from Tricholestes criniger (Blyth, 1845) (Pycnonotidae); Anonchotaenia kornyushini sp. nov. (Paruterinidae) from Trichastoma malaccense (Hartlaub, 1844) (Pellorneidae); Biuterina jensenae sp. nov. (Paruterinidae) from Chloropsis cochinchinensis (Gmelin, 1789) (Irenidae); Raillietina hymenolepidoides sp. nov. (Davaineidae) and R. mahnerti sp. nov. (Davaineidae) from Chalcophaps indica (Linnaeus, 1758) (Columbidae). Ophryocotyloides dasi Tandan \& Singh, 1964 is reported from Psilopogon henricii (Temminck, 1831) (Ramphastidae). Several other taxa in Dilepididae, Davaineidae, Paruterinidae, Hymenolepididae and Mesocestoididae, either potentially new or poorly known, are also reported. The richness described from this small collection hints at the potentially huge unknown parasite diversity from wild hosts in this part of the world.
\end{abstract}

Keywords. Avian hosts, Asia, Dilepididae, Davaineidae, Paruterinidae, Hymenolepididae, Mesocestoides.

Mariaux J. \& Georgiev B.B. 2020. Cestode parasites (Neodermata, Platyhelminthes) from Malaysian birds, with description of five new species. European Journal of Taxonomy 616: 1-35.

https://doi.org/10.5852/ejt.2020.616

\section{Introduction}

Between 2008 and 2017, a worldwide concerted effort was made to document the diversity of cestodes in their vertebrate hosts (Caira \& Jensen 2017). In this context, a team of taxonomists led by the present authors focused on avian parasites, with a particular focus on Cyclophyllidea of terrestrial birds (Mariaux et al. 2017). This resulted in various expeditions targeting particularly understudied hosts and regions (for previously published results, see Dimitrova et al. 2013, 2017, 2019; Widmer et al. 
2013; Phillips et al. 2014; Mariaux \& Georgiev 2018a, 2018b). The present contribution reports on the parasite fauna of a small collection of terrestrial birds examined in a well-conserved area of secondary and primary forest in Selangor State, North of Kuala Lumpur, Malaysia. Data for cestode parasites in this part of the world are scarce and most hosts examined were investigated for the first time. As expected, an important proportion of their parasitic fauna was unknown, leading us to describe five new species herein. An additional new hymenolepidid species from a kingfisher (Alcedinidae) will be treated elsewhere.

\section{Material and methods}

Hosts were collected with mist nets by the authors during a field expedition in Malaysia from July 27 to August 12, 2010. All collections were made at, or in the vicinity of, University of Malaya's Gombak Field Station, Selangor, Malaysia $\left(3.32^{\circ} \mathrm{N}, 101.77^{\circ} \mathrm{E}\right)$, altitude $280-350 \mathrm{~m}$. Birds were sorted at mist net side and those not necessary for the study were released on the spot. Selected birds were transported to the lab in fabric bags, euthanized as soon as possible with an excess of chloroform, photographed and identified. Dissections were made under a stereo microscope. The digestive tract was removed (possibly cut in sections depending on its size) and cut open. Cestodes were collected and preliminarily identified as far as possible. Specimens for morphological analysis were fixed with hot $4 \%$ formalin and transferred to $70 \%$ ethanol. When practicable, a piece of a voucher specimen was kept in molecular grade $99 \%$ ethanol and the corresponding specimen was fixed as above in a separate vial. Specimens were prepared using Mayer's hydrochloric carmine staining, dehydration in an ethanol series, clearing in eugenol (clove oil) and mounting in Canada balsam. Some scoleces were squashed in Berlese's medium to facilitate examination of rostellar hooks. When necessary, pieces of worms were embedded in paraffin and cross-sections (12-15 $\mu \mathrm{m}$ thick) were prepared. Sections were stained with Weigert's haematoxylin and counterstained with eosin. Except for tetrathyridia, all material discussed herein was collected in the host small intestine.

All measurements are given in micrometers (if not indicated otherwise) as the range, with the mean and the number (n) of measurements or counts in parentheses. Standard conventions for Dilepididae descriptions follow Bona (1994: 446). All specimens are deposited in the Platyhelminthes Collections of the Museum of Natural History (MHNG-PLAT) in Geneva, Switzerland. Partial COI (cox1) sequences were generated according to the methodology described in Scholz et al. (2013). These sequences are deposited in GenBank under accession numbers MN590285 to MN590294 (data by A. Waeschenbach and D.T.J Littlewood, Natural History Museum, London, UK).

Due to the use of bird bodies for other studies by the staff of the University of Malaya, Kuala Lumpur, only about half of the examined host individuals were prepared for preservation in museum collections; these were registered in the bird collections of the MHNG. The nomenclature of birds follows the last available edition of Avibase (Lepage 2019).

\section{Repositories}

$\begin{aligned} \text { MHNG-PLAT = } & \text { Platyhelminthes Collections, Museum of Natural History, Geneva, Switzerland } \\ \text { NHM } & \text { Natural History Museum, London, UK } \\ \text { SAM-AHC } & \text { South Australian Museum, Australian Helminthological Collection, Adelaide, } \\ & \text { Australia }\end{aligned}$

\section{Results}

Our fieldwork included the examination of 90 hosts specimens distributed in 14 families (mostly of Passeriformes) and 37 species. Seventeen birds (15.3\%), belonging to 11 species in the Columbidae, Halcyonidae, Irenidae, Malaconotidae, Motacillidae, Muscicapidae, Pycnonotidae, Sylviidae and 
Timaliidae harboured cestodes, in line with expected prevalences for terrestrial birds (Mariaux et al. 2017). All identified cestodes belong to the Cyclophyllidea. Here we report on 13 taxa, including five new species.

The hosts examined have also been used to characterize the diversity of other parasite groups, resulting in a diversity survey of their haemosporidian parasites (Ivanova et al. 2015) and the description of two new acuariid nematode species (Mutafchiev et al. 2014).

Class Cestoda van Beneden, 1848

Order Cyclophyllidea van Beneden in Braun, 1900

Family Dilepididae Fuhrmann, 1907

Genus Emberizotaenia Spasskaya, 1970

Emberizotaenia aeschlii sp. nov.

urn:1sid:zoobank.org:act:AF7C4CCB-7621-4DA1-B97E-2DD43AAFC4E2

Figs 1-3, Table 1

\section{Etymology}

The species is dedicated to the late Prof. André Aeschlimann, parasitologist and mentor of the senior author, who was familiarly known as "Aeschli" to his colleagues and students.

\section{Material examined}

Holotype

MALAYSIA • Selangor, University of Malaya's Gombak Field Station; $3.32^{\circ} \mathrm{N}, 101.77^{\circ} \mathrm{E} ; 280-350 \mathrm{~m}$ a.s.1.; 31 Jul. 2010; no molecular voucher; MHNG-PLAT-120682.

\section{Comparative material}

AUSTRALIA - transverse sections of syntypes of Emberizotaenia chlamyderae (Krefft, 1871) Bona, 1994 from Chlamydera maculata (Gould, 1837) (Passeriformes, Ptilonorhynchidae); SAM-AHC 20445.

\section{Type host}

Tricholestes criniger (Blyth, 1845) (Passeriformes, Pycnonotidae).

\section{Prevalence}

$17 \%(1 / 6)$.

\section{Description}

Body small, $22.5 \mathrm{~mm}$ long, with maximum width 1075 at level of pregravid proglottides; consisting of 115 proglottides (last proglottides pregravid). Proglottides craspedote, always wider than long. Scolex rounded, not delineated from neck, 430 in diameter (Fig. 1). Suckers rounded, 185-200 $(194, \mathrm{n}=4)$ in diameter; muscular, unarmed. Rostellar apparatus unarmed, weakly muscular, with well-developed glandular tissue within rostellar sac, especially in its posterior half. Rostellar sac regular, cylindrical, almost reaching level of posterior margin of suckers, $225 \times 88$. Rostellum discrete, poorly delineated and very weak, $64 \times 20$, glandular. Proglottization distinct at 300 from posterior margin of suckers. Genital pores situated in anterior $25 \%$ of length of lateral proglottis margin, irregularly alternating in very short series, e.g., 2, 2, 2, 1, 2, 1, 3, 1, 3, 1, 2, 1; no more than 4 consecutive pores observed on one side. Ventral osmoregulatory canals up to 40 wide, connected posteriorly in each proglottis by transverse anastomosis. Dorsal osmoregulatory canals 6-7 wide. Genital ducts passing between osmoregulatory canals. Genital atrium small, sink-shaped, up to about 18-22 deep and 15-17 in diameter. 
Testes $26-34(29, \mathrm{n}=14)$ in number; in 2 or 3 layers, in one continuous posterior field, sometimes overlapping osmoregulatory canals and often overlapping posterior lobes of ovary and vitellarium (Fig. 2). External vas deferens convoluted in antero-poral part of median field. Cirrus-sac elongate, 170-212 × 36-50 $(191 \times 43, \mathrm{n}=20)$, usually straight, crossing osmoregulatory canals; distal extremity with large cells (Fig. 3). Internal vas deferens forming several coils, mostly in proximal half of cirrus sac. Cirrus unarmed, about 100-130 long and usually straight when invaginated.
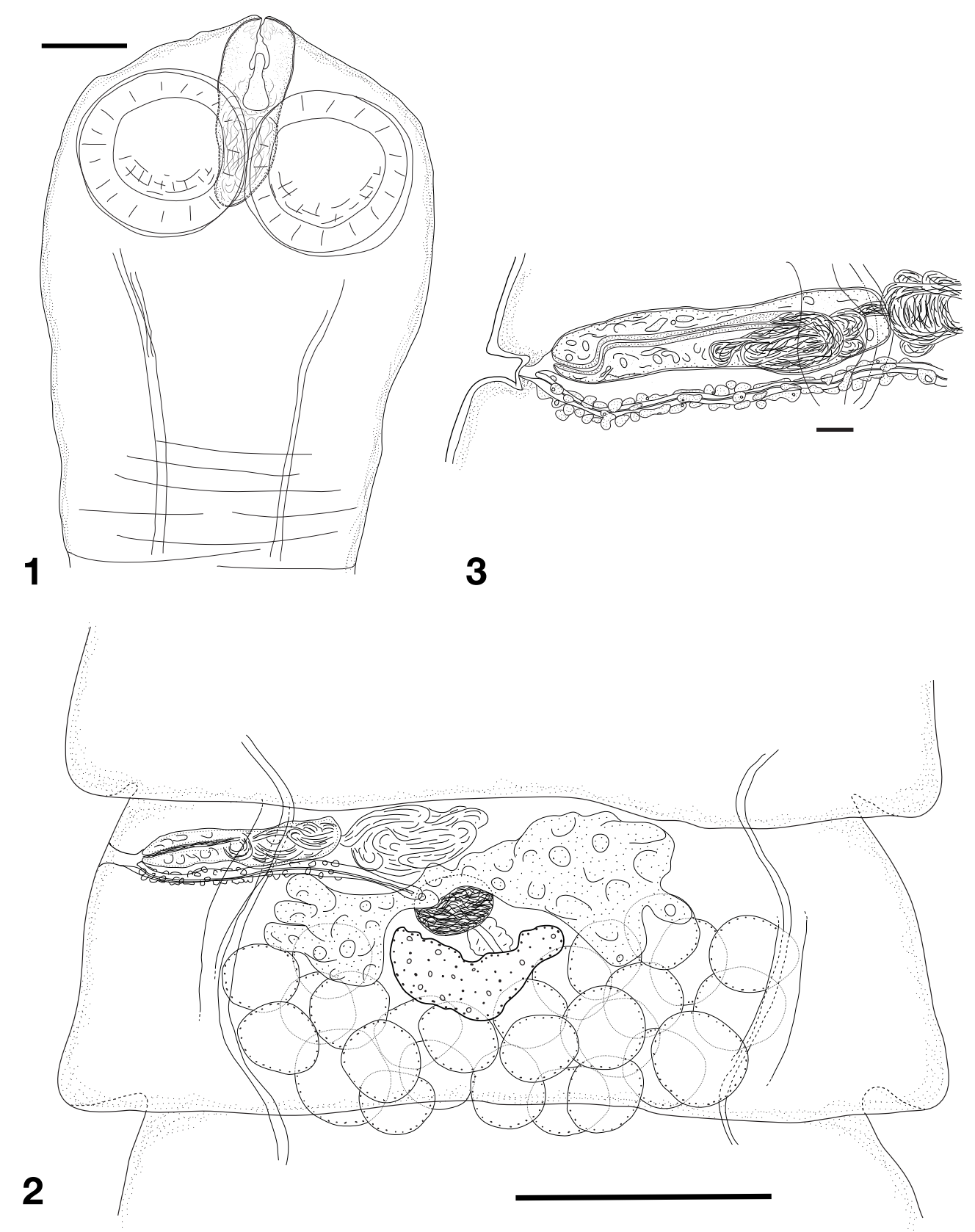

Figs 1-3. Emberizotaenia aeschlii sp. nov. 1. Scolex. 2. Mature proglottis, ventral view. 3. Cirrus-sac. Scale bars: $1=100 \mu \mathrm{m} ; 2=250 \mu \mathrm{m} ; 3=20 \mu \mathrm{m}$. 
Vitellarium central, compact, transversely elongate, variable in shape but often forming a flattened $\mathrm{V}$ or reniform. Ovary antero-central, transversely elongate, bi-alate, multilobate, antiporal wing larger than poral wing; not overlapping longitudinal osmoregulatory canals. Mehlis' gland subglobular, anterior to vitellarium. Seminal receptacle round, becoming more oval when full but never elongated, reaching up to $190 \times 145$ in pregravid proglottides, dorsal and between ovary wings. Vagina opens posterior to male pore, straight and transverse, parallel to cirrus-sac; thick-walled, surrounded by a loose sheath of large cells irregularly positioned along entire canal; no vaginal sphincter (Fig. 3).

Uterus starts its development in late mature proglottides as a diffuse ventral reticulum, progressively forming numerous small lobes and occupying entire median field; crossing osmoregulatory canals and extending into lateral fields. Uterus eventually becoming sacciform with deep septa. Developing oncospheres round, 19-21 in diameter, no fully developed eggs or embryonic hooks observed.

\section{Remarks}

Dilepidids with a reduced, unarmed, apical apparatus belong to a number of genera. An important differentiating character for distinguishing among them is the presence (or not) of a rudimentary unarmed rostellum, or "bulb" (Bona 1994). This structure is a diagnostic character of two genera, Eburneotaenia Bona, 1994, with type species E. eburnea (Mariaux \& Vaucher, 1988), characterised also by the presence of sucker armature consisting of small punctiform spines (see Mariaux \& Vaucher 1988), and Emberizotaenia Spasskaya, 1970, which has unarmed suckers. Our specimen has such an unarmed bulb, albeit weak, and has unarmed suckers. Therefore, it belongs to Emberizotaenia, a genus known from birds of the order Passeriformes in the Palaearctic Region and in Australia. Bona (1994) mentioned Africa and Sri Lanka in the geographical range of this genus but without further explanation or reference; we consider the information about these geographical areas may come from his personal unpublished data.

The new species described here essentially fits the generic diagnosis proposed by Bona (1994). There is an exception related to the number of testes, which are "numerous" (26-34) in our material, instead of "very numerous" as mentioned in the generic diagnosis; according to Bona (1994), the adopted range for "very numerous testes" refers to "from about 36 to 60, seldom more". However, the type species E. reductorhyncha (Spasskaya, 1957), as well as E. skrjabiniana (Spasskaya, 1958), also have "numerous" testes (Table 1), i.e., between 14 and 35 according to Bona's (1994) definition. In addition, we could not observe the osmoregulatory canals forming a network posterior to the scolex in our specimens; this character may, however, be difficult to observe depending on the state of conservation and the fixation of the material, and has not been reported in the original descriptions of the majority of the known species. Therefore, we doubt that it is a reliable character to be used for generic differentiation.

Currently, the genus Emberizotaenia includes 4 species:

1. Emberizotaenia reductorhyncha (Spasskaya, 1957) (type species) [Anomotaenia reductorhyncha Spasskaya, 1957; Unciunia reductorhyncha in Matevosyan 1963; Ptilotolepis reductorhyncha in Spasskaya \& Spasskii 1977], originally described from Poecile cinctus (Boddaert, 1783) (syn. Parus cinctus) (Paridae) from Vilyuyskiy Rayon, Yakutia, Russia (Spasskaya 1957). Subsequently, this species was redescribed and illustrated from "Parus atricapillus" from Tuva (Russia); however, Poecile atricapillus is currently believed to represent a North American species (Lepage 2019) and this record probably refers to $P$. montanus Conrad von Baldenstein, 1827. Other host records are those from P. palustris Linnaeus, 1758 from Tuva (Spasskaya \& Spasskii 1971) and from Parus major Linnaeus, 1758 from Ukraine (Salamatin 1999). The records of E. reductorhyncha from Turdus philomelos Brehm, 1831 (= Turdus ericetorum) from Moldova (Shumilo \& Spasskaya 1975; Spasskaya \& Spasskii 1977) and Kaliningradskaya Oblast' of Russia (Galkin 1981) most 
Table 1. Main morphological characteristics of species of Emberizotaenia Spasskaya, 1970. * With additional counts or measurements from sections of type material.

\begin{tabular}{lccccc}
\hline & E. aeschlii sp. nov. & $\begin{array}{c}\text { E. reductorhyncha } \\
\text { (Spasskaya, 1957) }\end{array}$ & $\begin{array}{c}\text { E. skrjabiniana } \\
\text { (Spasskaya, 1958) }\end{array}$ & $\begin{array}{c}\text { E. raymondi (Gigon } \\
\text { \& Beuret, 1991) }\end{array}$ & $\begin{array}{c}\text { E. chlamyderae } \\
\text { (Krefft, 1873) }\end{array}$ \\
\hline Source & Present study & Spasskaya (1957) & Spasskaya (1958) & $\begin{array}{c}\text { Gigon \& Beuret } \\
(1991)\end{array}$ & Krefft (1873) \\
Host family & Pycnonotidae & Paridae & Emberizidae & Turdidae & Ptilonorhynchidae \\
Type locality & Malaysia & $\begin{array}{c}\text { Yakutia (= Sakha), } \\
\text { Russia }\end{array}$ & Tuva, Russia & Switzerland & Australia \\
$\begin{array}{l}\text { Body length } \times \text { width } \\
\text { [mm }]\end{array}$ & $22.5 \times 1.075$ & $30-35 \times 1.5$ & $30 \times 1$ & $25-39 \times 1.3$ & ca 76.2 $\times 2.12$ \\
Scolex diameter & 430 & $392-686$ & 475 & $590-750 \times 490-700$ & - \\
Sucker diameter & $185-200$ & $168 \times 154$ & - & $260-270$ & - \\
Rostellum & $64 \times 20$ & $72 \times 41$ & $135 \times 81$ & $60-70 \times 30-40$ & - \\
Rostellar sac & $225 \times 88$ & $168 \times 112$ & $320 \times 330$ & $200-260 \times 140-160$ & - \\
Testes number & $26-34$ & $16-20$ & 30 & $30-40$ & $<20 ? *$ \\
Cirrus sac & $170-212 \times 36-50$ & $145 \times 38$ & $248-256 \times 41$ & $170-280 \times 40-50$ & $90-137 \times 27-41^{*}$ \\
Oncospheres & $19-21$ & $36 \times 29$ & $39 \times 25$ & $27-31 \times 19-25$ & - \\
\hline
\end{tabular}

probably refer to another congeneric species, E. raymondi (see Georgiev \& Genov 1993). Therefore, E. reductorhyncha is a specific parasite to birds of the family Paridae known from the Northern Palaearctic.

2. Emberizotaenia skrjabiniana (Spasskaya, 1958) Spasskaya, 1970 [Anomotaenia skrjabiniana Spasskaya, 1958; Pseudanomotaenia skrjabiniana in Matevosyan 1963; Ptilotolepis skrjabiniana in Spasskaya \& Spasskii 1977] from Emberiza leucocephalos Gmelin, 1771 (Emberizidae) from Tuva (Russia) (Spasskaya 1958). Kornyushin (1972) reported this species from Ukraine but without providing data on its host and morphology. Spasskaya \& Spasskii (1977) mentioned it from Galerida cristata (Linnaeus, 1758) (Alaudidae) from Nakhchivan Autonomous Republic (Transcaucasia) on the basis of the unpublished dissertation by Sadykhov but this record needs additional confirmation. Ryšavý (1979) believed that the original description by Spasskaya (1958) had been based on specimens with lost rostellar hooks and identified cestodes with armed rostella from Fringilla coelebs Linnaeus, 1758 (Fringillidae) from Czechia as this species; the details in the description given by Ryšavý (1979) do not allow the identification of his cestodes at the generic level. Therefore, the only reliable report of E. skrjabiniana is the original description by Spasskaya (1958).

3. Emberizotaenia raymondi (Gigon \& Beuret, 1991) [Unciunia raymondi Gigon \& Beuret, 1991; Ptilotolepis raymondi in Georgiev \& Genov 1993; Ptilotolepis philomelae Okulewicz, 1991] from Turdus philomelos (Turdidae) from Switzerland (type locality) (Gigon \& Beuret 1991), Poland (Okulewicz 1991), Bulgaria (Georgiev \& Genov 1993) and, possibly from Moldova and Kaliningradskaya Oblast', Russia (as Emberizotaenia reductorhyncha, see above). Therefore, for the moment, this species is a specific parasite of Turdus philomelos known from Europe only.

4. Emberizotaenia chlamyderae (Krefft, 1873) [Taenia chlamyderae Krefft, 1873; Choanotaenia chlamyderae in Johnston 1911; Icterotaenia chlamyderae in Baer 1925; Paricterotaenia chlamyderae in Fuhrmann 1932; Polycercus chlamyderae in Schmidt 1986] from Chlamydera maculata (Gould, 1837) (Ptilonorhynchidae) from New South Wales, Australia, known from its original description (Krefft 1873) and a drawing of the scolex by Bona (1994). Unfortunately, most of Krefft's material, 
including specimens observed by Bona, seems to be lost, with only 3 slides of sections remaining. These allowed us to obtain a few measurements of the cirrus-sac at $111 \times 33(90-137 \times 27-41, n=7)$, as well as to obtain a very rough estimate of testis number, probably less than 20 (Table 1).

Even in the absence of gravid proglottides, our specimen is unambiguously distinguishable from all of them (Table 1). It differs from E. reductorhyncha by the higher number of testes (26-34 vs 16-20) and a longer cirrus sac (170-212 vs 145); from E. skrjabiniana by its smaller cirrus sac (170-212 vs $248-256)$ and smaller rostellar sac $(225 \times 88$ vs $320 \times 330)$. Our material is more similar to E. raymondi. Metrical characters in both taxa are very similar, but a number of differences nevertheless allow them to be distinguished morphologically. The most obvious ones are the shape of the rostellar pouch, which is globular in E. raymondi and more elongated in our material, as well as the presence of distinctive large cells making a loose sheath around a strongly walled vagina in the Malaysian material. Additionally, E. raymondi has as larger scolex and suckers; a more elongate cirrus sac, a higher proportion of it extending in median field; and a smaller seminal receptacle. From E. chlamyderae, a species with very poorly known anatomy, our specimen differs by its three times smaller body length, a larger cirrus-sac and, possibly, higher number of testes.

Together with the host and the geographical origin of our material, these observations allow its recognition as a new species, Emberizotaenia aeschlii sp. nov. Pycnonotidae represents a new host family for this genus of cestodes.

Genus Sobolevitaenia Spasskaya \& Makarenko, 1965

Sobolevitaenia anthusi (Spasskaya, 1958)

Figs 4-7

\section{Material examined}

MALAYSIA 22 specs (in fragments, one without gravid proglottides); Selangor, University of Malaya's Gombak Field Station; $3.32^{\circ}$ N, $101.77^{\circ}$ E; 280-350 m a.s.1.; 11 Aug. 2010; no COI sequence successfully retrieved; MHNG-PLAT-121462.

\section{Host}

Motacilla cinerea Tunstall, 1871 (Passeriformes, Motacillidae).

\section{Description}

Body of small size, with length up to $25.5 \mathrm{~mm}$ and maximum width 720 at level of gravid proglottides; consisting of at least 101 proglottides. Proglottides craspedote, initially wider than long but rapidly elongating; gravid proglottides up to 2.5 times as long as wide. Scolex elongate, fragile, $112-150$ in diameter (Fig. 4). Suckers rounded, 82-95 $(89, \mathrm{n}=8)$ in diameter, weakly muscular, with internal surface covered by small shovel-shaped spines, ca 2.5 wide (Fig. 5). Rostellar sac large, filling most of scolex volume, cylindrical, passing beyond level of posterior margin of suckers, 175-185 $\times 77$. Rostellum large, well-delineated and weakly muscular, $150-155 \times 70-72$. Hooks 20 in number, in 2 poorly delineated rows; each hook with short blade and guard and long handle (Fig. 6). Anterior hooks 30-33 (32, n=6) long. Posterior hooks 26.5-30 (27.5, $\mathrm{n}=9)$ long. Proglottization distinct at 138-160 from posterior margin of suckers. Genital pores situated anteriorly at $20-25 \%$ of length of lateral proglottis margin, irregularly alternating in very short series; no more than 3 consecutive pores observed on one side. Ventral osmoregulatory canals up to 20 wide, more commonly 5-10 wide, connected posteriorly in each proglottis by transverse anastomosis. Dorsal osmoregulatory canals narrow, 2-4 wide. Genital ducts passing between osmoregulatory canals. Genital atrium small, unremarkable. 
Testes 17-21 $(18.5, \mathrm{n}=23)$ in number; in 2 layers, in one continuous posterior field, not overlapping osmoregulatory canals and rarely overlapping posterior lobes of ovary and vitellarium (Fig. 7). External vas deferens coiled anteriorly, overlapping proximal extremity of cirrus-sac. Cirrus-sac elongate, strong and very large, 183-228 $\times 35-45(201 \times 41, \mathrm{n}=14)$, often slightly bent anteriorly at mid-length, reaching or extending beyond middle of proglottis. Internal vas deferens forming several coils, mostly in proximal third of cirrus-sac. Cirrus armed with well-developed spines of various sizes; spines smaller proximally and less numerous, stronger and larger distally, up to 5 long.

Vitellarium central, compact, globulous, particularly large, 70-110 $\times 90-140(86 \times 109, \mathrm{n}=7)$ in late mature proglottides. Ovary antero-central, bi-alate, longitudinally elongate, large; antiporal wing slightly larger than poral wing; not overlapping longitudinal osmoregulatory canals. Mehlis' gland globular, immediately anterior to vitellarium. Seminal receptacle oval, central, dorsally overlapping ovary and, possibly, vitellarium in part, reaching up to $225 \times 175$ in pregravid proglottides. Vagina opens posterior to male pore, well-marked with compact cellular sheath over its entire length, straight and transverse, parallel to cirrus-sac up to two thirds of its length, then markedly bent posteriorly, sometimes partially overlapping cirrus-sac dorsally (Fig. 7).

Uterus starts its development as a diffuse reticulum, progressively forming numerous small lobes and occupying entire median field; crossing osmoregulatory canals and extending in lateral fields. Uterus eventually becoming multisaccular, almost labyrinthine. Embryophores thick. Oncospheres oval, 26$31 \times 20-23(28 \times 21, \mathrm{n}=15)$. Embryonic hooks 10 long.

\section{Remarks}

This material presents all the characters of the genus Sobolevitaenia, a genus found in various passerines, including Motacillidae, that we recently discussed in detail (Mariaux \& Georgiev 2018b). In that work, we presented a summary of the main metrical and meristic characters of the 17 known species of the genus. Most of them differ obviously from the present material because of their (mostly larger) hook length, number of testes or cirrus-sac length.

The most similar taxa are the type-species $S$. anthusi (Spasskaya, 1958) and its possible synonym S. orientalis Spasskii \& Konovalov, 1969, which are found in various Motacillidae, rarely in other passerines, in the Palaearctic (Spasskaya \& Spasskii 1977). Although some variation is known for this taxon, $S$. anthusi shows a rostellar armature and number of testes similar to the present material. It differs, however, essentially by having a shorter cirrus-sac (that also has a more limited extension across the proglottis), a longer rostellar sac, and a shorter rostellum. Its strobila is also shorter, not exceeding $15 \mathrm{~mm}$ (Spasskaya \& Spasskii 1977). Sobolevitaenia orientalis has a different subset of differentiating characters, including a larger scolex, a shorter rostellar sac and slightly larger posterior hooks.

Finally, S. (?) borealis (Krabbe, 1869) also show characteristics similar to the present material. However, besides its very different hosts (Calcariidae) and distribution (Greenland), this poorly known taxon also has a larger scolex, only 18 rostellar hooks and shorter posterior hooks (according to Baer 1956).

The status of $S$. anthusi as a single species or a complex of similar species, and its possible synonymy with $S$. orientalis, remains unclear. Our material differs slightly from both original descriptions but would be included in the global variation of both taxa taken together. In addition, $S$. anthusi has been reported with significant morphological variation across its range that extends at least along the entire north coast of Russia and south to Tajikistan and Tuva. Those elements may be indicative of a complex of species, but for now we will take the cautious option of placing our material in S. anthusi sensu Spasskaya \& Spasskii (1977). 

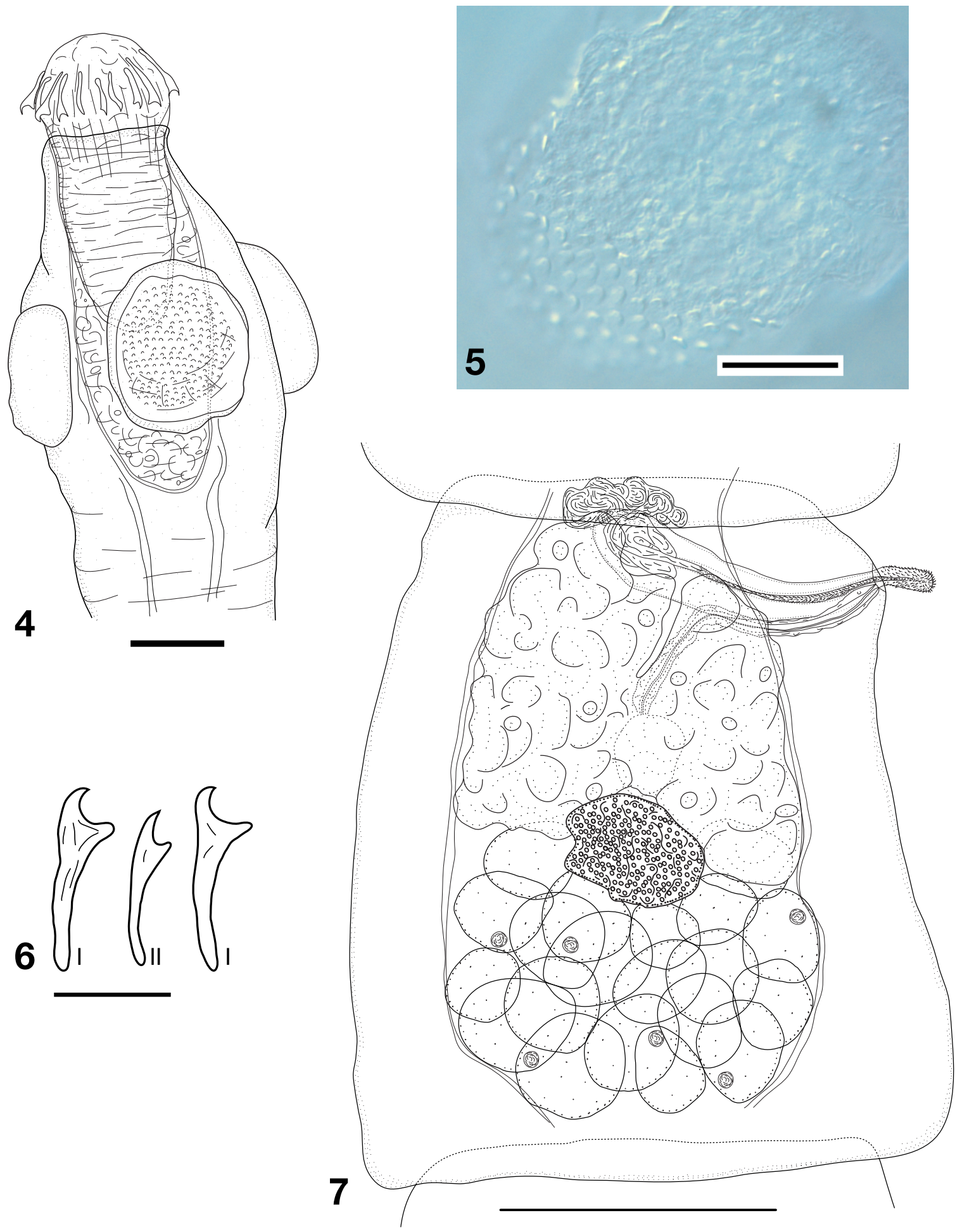

Figs 4-7. Sobolevitaenia anthusi (Spasskaya, 1958). 4. Scolex. 5. Sucker spines. 6. Rostellar hooks (I: anterior, II posterior). 7. Mature proglottis, ventral view. Scale bars: $4=50 \mu \mathrm{m} ; 5-6=20 \mu \mathrm{m}$; $7=200 \mu \mathrm{m}$. 
Dilepididae gen. sp.

\section{Material examined}

MALAYSIA - 1 spec. (in fragments); Selangor, University of Malaya's Gombak Field Station; $3.32^{\circ} \mathrm{N}, 101.77^{\circ} \mathrm{E} ; 280-350 \mathrm{~m}$ a.s.1.; 11 Aug. 2010; no COI sequence successfully retrieved; MHNGPLAT-121225.

\section{Host}

Orthotomus sericeus Temminck, 1836 (Passeriformes, Cisticolidae).

\section{Remarks}

Our specimen is about $32 \mathrm{~mm}$ long, with a maximum width of 850 . It consists of 64 proglottides which very rapidly become longer than wide. The anatomy is typical for a member of the Dilepididae: numerous testes (18-27) in one posterior field; irregularly alternating genital pores opening at anterior $20 \%$ of proglottis margin; unarmed cirrus; oval cirrus-sac reaching osmoregulatory canals; genital ducts passing between osmoregulatory canals; a large two-winged central ovary. Uterus is densely labyrinthine. Unfortunately, no scolex is available and a more precise identification is not possible. To our knowledge, no cestode had previously been reported from this host species or, indeed, from any of the 12 other species of tailorbirds.

Family Paruterinidae Fuhrmann, 1907

Genus Anonchotaenia Cohn, 1900

Anonchotaenia kornyushini sp. nov. urn:lsid:zoobank.org:act:7CB90CCB-EC69-401F-AAA6-10A697956E1A

Figs $8-13$

\section{Etymology}

The species is dedicated to our colleague Prof. Vadim V. Kornyushin (Kiev, Ukraine), a dedicated cestode taxonomist with numerous contributions to the knowledge of the family Paruterinidae.

\section{Material examined}

Holotype

MALAYSIA • Selangor, University of Malaya's Gombak Field Station; $3.32^{\circ}$ N, $101.77^{\circ}$ E; $280-350 \mathrm{~m}$ a.s.1.; 9 Aug. 2010; MHNG-PLAT-121232.

\section{Paratypes}

MALAYSIA • 2 specs; same collection data as for holotype; MHNG-PLAT-121233.

\section{Hologenophore}

MHNG-PLAT-121234 [field \# MAL-075/C3]. Partial COI sequence, Genbank MN590285.

\section{Type host}

Trichastoma malaccense (Hartlaub, 1844) (Passeriformes, Pellorneidae).

\section{Description}

Body of medium size, $42 \mathrm{~mm}(\mathrm{n}=1)$ long, with maximum width 930 at level of early gravid proglottides; consisting of 540 proglottides. Mature proglottides acraspedote, about 15-20 times as wide as long; progressively becoming longer, $8-10$ times wider at pregravid stage, then becoming markedly craspedote 
when gravid; last gravid proglottides almost as long as wide. Scolex rounded, $710-760(730, n=3)$ in diameter, poorly delineated from strobila. Suckers strong, muscular, 300-350 $(327, \mathrm{n}=12)$ in diameter. Rostellum and rostellar sac absent (Fig. 8). Unsegmented zone 1.7-1.8 mm long behind posterior margin of suckers. Genital pores irregularly alternating in short series (mostly 1 or 2, maximum of 5 consecutive pores on the same side), opening in middle of lateral margin of proglottis. Genital ducts ventral to osmoregulatory canals. Ventral osmoregulatory canals up to 75 wide, connected posteriorly in each proglottis by transverse anastomosis. Dorsal osmoregulatory canals 5-10 wide. Genital atrium simple, with narrow infundibular orifice, $17-25$ deep.

Testes large, spherical to slightly oval, 6-9 in number [6 (19\%), 7 (37.5\%), 8 (36\%), 9 (7.5\%)] (7.3, $\mathrm{n}=53) ; 43-62(50, \mathrm{n}=20)$ in diameter; arranged in single transverse row (with some partial overlapping) situated dorsally, occupying entire median field. Cirrus sac discrete, claviform, straight, with narrow poral half; not reaching osmoregulatory canals, 93-114 $\times 26-36(103 \times 30, \mathrm{n}=30)$. Cirrus unarmed. Internal vas deferens making a few loops in cirrus sac. External vas deferens coiled, situated antiporally to cirrus sac (Figs 9-10).

Vitellarium compact, oval, $45-55 \times 58-80(51 \times 67, \mathrm{n}=20)$; aporal to ovary or partially overlapping its antiporal extremity dorsally. Ovary oval, $57-85 \times 100-148(68 \times 123, n=20)$; in poral half of median field. Mehlis' gland not distinct. Vagina well-marked, opening posterior to male pore. Seminal receptacle oval to fusiform, on poral side of developing uterus. Uterus saccular, appearing centrally, dorsal to ovary in post-mature and pregravid proglottides, expanding laterally, becoming teardrop-shaped with thicker poral extremity (Fig. 11), then becoming more and more globular. Uterine wall thick. Paruterine organ consisting of fibrillar tissue, appearing rapidly adjacent to developing uterus, directed anteriorly to it and progressively becoming thicker (Figs 12-13). Eggs initially spherical, becoming vermiform in gravid proglottides, gradually filling uterus. At spherical stage, oncospheres $12.5-16.5(14, \mathrm{n}=20)$ and eggs $18-20.5(19.5, \mathrm{n}=20)$ in diameter. Embryonic hooks (poorly visible) ca 8 in length. Eggs passing into paruterine cavity not observed, but most developed proglottides with antero-central densification suggesting formation of this cavity.

\section{Remarks}

This material belongs to the genus Anonchotaenia Cohn, 1900 as defined by Mariaux (1991) or Georgiev \& Kornyushin (1994). The most recent review of its diversity was by Phillips et al. (2014), who presented a summary of the main characters of the known species. Subsequently, a single additional species, A. adhiraji Banerjee, Manna \& Sanyal, 2018, was described in India (Banerjee et al. 2018). This allows the easy comparison of our material with the 30 known species of Anonchotaenia. Most of Anonchotaenia spp. clearly differ by more than one of the characters listed by Phillips et al. (2014) (scolex and sucker diameters, position of genital ducts, testis number, cirrus sac extent and size) and only 2 species are similar to our material, i.e., A. castellanii Fuhrmann \& Baer, 1943, described from an Ethiopian laniid bird, and A. globata (von Linstow, 1879), initially described from a parid bird from Germany (von Linstow 1879). The former species exhibits close similarities with our material; however, its testis number (9-10) is only marginally overlapping our observations (6-9, with a dominant proportion of 7-8 testes). Anonchotaenia castellanii further differs from our material in showing a much more muscular cirrus-sac as well as a strong atrial sphincter (Fuhrmann \& Baer 1943). Furthermore, Eurocephalus rueppellii Bonaparte, 1853, the host of A. castellanii, is endemic to Eastern Africa.

Anonchotaenia globata has been reported from a wide range of Passeriformes all over the world (Matevosyan 1969). It also resembles our material for most characters, even if a precise description of this species is difficult to infer from the multiple reports of this taxon. Kornyushin (1989) believed that the reports of $A$. globata should be referred to a complex of species. Philips et al. (2014) presented metrical data based on summarising known ranges reported for $A$. globata by many authors from various 

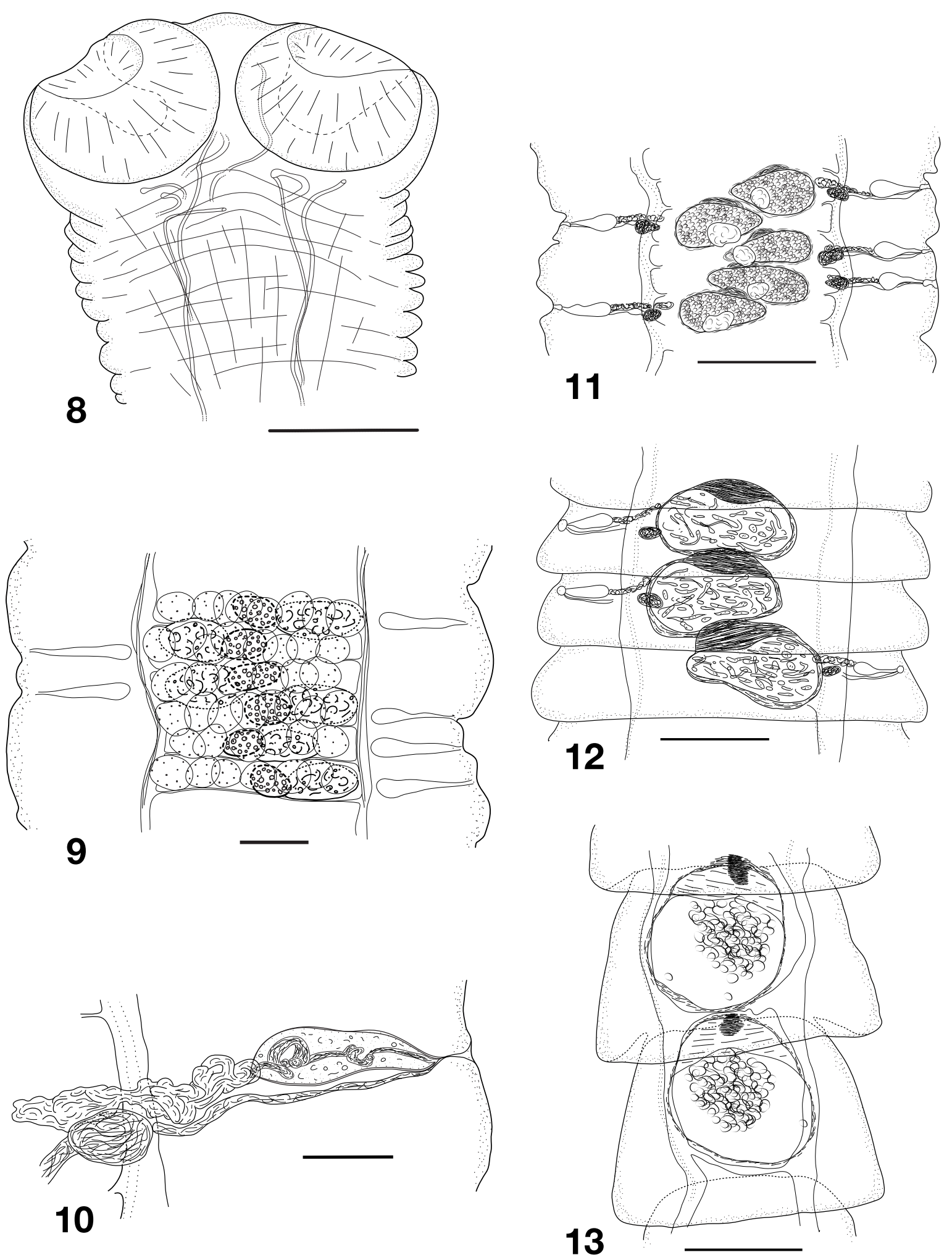

Figs 8-13. Anonchotaenia kornyushini sp. nov. 8. Scolex. 9. Mature proglottis. 10. Cirrus-sac, dorsal view. 11-13. Various stages of uterine and paruterine organ development. Scale bars: $8-9=100 \mu \mathrm{m}$; $10=50 \mu \mathrm{m} ; 11-13=250 \mu \mathrm{m}$. 
hosts and various geographical origins (but erroneously mentioning in their table that these data come from the original description only). Even considered in this wide and doubtful taxonomic context, A. globata is characterized by a smaller number of testes (4-5) than our material, though a larger range has occasionally been reported for this species. Although a few other unusual morphological characters (such as the changes of the shape of the paruterine organ during its development) seem promising for specific identifications in the group (Phillips et al. 2014), they still lack a complete comparative basis. Testis number presently remains crucial, and the most reliable criterion to identify Anonchotaenia spp. at the morphological level (Mariaux 1991). We consider it sufficient to justify the placement of our material in a new species that we name Anonchotaenia kornyushini sp. nov.

Genus Biuterina Fuhrmann, 1902

\section{Biuterina jensenae sp. nov. urn:1sid:zoobank.org:act:5B34DD7D-6AA3-43A3-A8B3-6423594ACD3E}

Figs 14-21

\section{Etymology}

The species is dedicated to our colleague Prof. Kirsten Jensen, University of Kansas, Lawrence, in recognition of her remarkable contribution to tapeworms systematics.

\section{Material examined}

Holotype

MALAYSIA • Selangor, University of Malaya's Gombak Field Station; $3.32^{\circ} \mathrm{N}, 101.77^{\circ} \mathrm{E} ; 280-350 \mathrm{~m}$ a.s.1.: 30 Jul. 2010; MHNG-PLAT-121156.

Paratypes

MALAYSIA • 1 fragment; same collection data as for holotype; MHNG-PLAT-121157.

\section{Hologenophore}

MHNG-PLAT-121157. Partial COI sequence, Genbank MN590287.

\section{Other material}

MALAYSIA - 3 juveniles from Tricholestes criniger (Blyth, 1845) (Passeriformes, Pycnonotidae); same locality as for type material; 5 Aug. 2010; partial COI sequence, Genbank MN590286; MHNGPLAT-121158.

\section{Type host}

Chloropsis cochinchinensis (Gmelin, 1789) (Passeriformes, Irenidae).

\section{Description (from type material)}

Worm with body of medium size, $36 \mathrm{~mm}$ long, with maximum width 1100 at level of gravid proglottides; consisting of 276 proglottides. Proglottides craspedote, wider than long except for very last gravid ones. Scolex poorly delineated from neck, 400 in diameter (Fig. 14). Suckers muscular, rounded, 185-200 $(190, \mathrm{n}=4)$ in diameter. Rostellum discoid, with strong conical anterior extremity, 128 in diameter, 95 in length, musculo-glandular, armed with a double crown of about 42 small triangular hooks of similar size, with short handle, more elongate in anterior row, more massive in posterior row, with reduced or indistinguishable epiphyseal thickenings. Length of anterior hooks 15.5-16 $(n=4)$, of posterior hooks 15-15.5 ( $\mathrm{n}=3$ ) (Fig. 15). Neck poorly marked, unsegmented zone extending to 900 from posterior margin of suckers. Genital pores irregularly alternating in short unequal series (e.g., ... 5, 1, 1, 1, 3, 7, 1, $2,1,2,1,1,2 \ldots)$; situated at anterior $40 \%$ of lateral proglottis margin. Ventral osmoregulatory canals up 
to 120 wide, connected posteriorly in each proglottis by transverse anastomosis. Dorsal osmoregulatory canals $10-15$ wide. Genital ducts between osmoregulatory canals. Genital atrium simple, narrow, inconspicuous.

Testes $9-13$ in number $(11, \mathrm{n}=11)$, in a single dorso-central field (Fig. 17). External vas deferens forming numerous compact coils situated in median field adjacent to antiporal extremity of cirrus-sac. Cirrus-sac cylindrical to pyriform, straight, thick-walled, not or just reaching excretory canals, 107$122 \times 41-51(114 \times 46, \mathrm{n}=14)$ (Figs 16-17); internal vas deferens forming a few coils in its proximal half. Cirrus unarmed.

Vitellarium posterior, central, compact and transversely elongate, 90-120 × 35-50 $(103 \times 41, \mathrm{n}=9)$. Ovary anterior and transversely elongate, poorly visible in our material. Vagina well-marked, with strong wall, opened posteriorly to male pore, then parallel to cirrus sac, straight. Seminal receptacle elongated and discrete, just poral to ovary or partially dorsal to it (Fig. 17).

Uterus starts its development as an antero-dorsal sac, developing into a transverse sac and rapidly forming 2 connected postero-lateral sacs containing developing eggs. Paruterine organ simultaneously formed anteriorly, then progressively posteriorly over uterus. Paruterine organ with compact walls but loose internal tissues. Connecting (transverse) part of uterus widening and developing anteriorly into paruterine organ together with eggs. Eggs eventually passing into fully developed paruterine organ; vestigial uterine sacs empty and progressively disappearing (Figs 18-20). Eggs oval, with thin outer envelope, 35-41 $\times 25-31(38 \times 27, \mathrm{n}=15)$ (Fig. 21). Oncospheres 25-30 $(26, \mathrm{n}=15)$. Lateral embryonic hooks 13-14 $(13.1, \mathrm{n}=15)$ long, central embryonic hooks $14-15(14.7, \mathrm{n}=10)$ long.

Additional data from juvenile specimens in T. criniger: Scolex diameter 370-385. Sucker diameter 190-217 (198, $\mathrm{n}=12)$. Rostellum 116-135 in diameter, 96-100 in length. Hook number 42-44, 15.5-17 in length.

\section{Remarks}

With its distinctive pair of uterine sacs, paruterine organ and typical rostellum, our material unambiguously belongs to the genus Biuterina Fuhrmann, 1902 as defined by Georgiev \& Kornyushin (1994). The last review of the group by Georgiev \& Mariaux (2007) reported 34 species in the genus and presented an identification key to the species. To our knowledge, no additional species has been reported since this publication. None of the species in this genus is known from Irenidae or Pycnonotidae, and only 3 of them have an Oriental distribution, all of them in India. No species of Biuterina spp. are known from SE Asia yet.

The majority of the known species differ markedly from our material by a combination of their rostellar hook numbers and length (which are mostly both more numerous and longer), resulting in only 2 species showing similar metric characters:

- Biuterina chlorurae (Rausch \& Schiller, 1949), a parasite of Pipilo chlorurus (Audubon, 1839) (Passerellidae) in Wyoming, USA. It differs from our material by showing fewer proglottides (140 vs 276), slightly longer (up to 20) rostellar hooks in two rows differing in length and shape, smaller seminal receptacle (20 in diameter), different development of the uterus (with uterine sacs not clearly separated) and larger eggs (43-50 in diameter).

- Biuterina dicruri Singh, 1964, from Dicrurus leucophaeus Vieillot, 1817 (Dicruridae) in North-East India. Its rostellar hooks are of different length on both rows. Although the testis number in this species overlaps that of our specimens, it most commonly has 7 testes against 11 on average in our material and its cirrus pouch is shorter $(80-110 \times 26-40)$. 


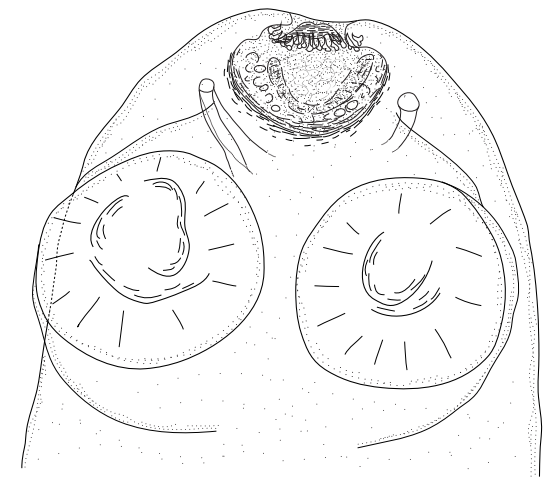

14

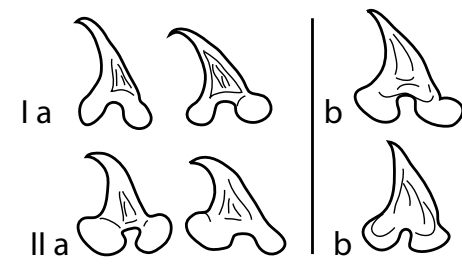

15

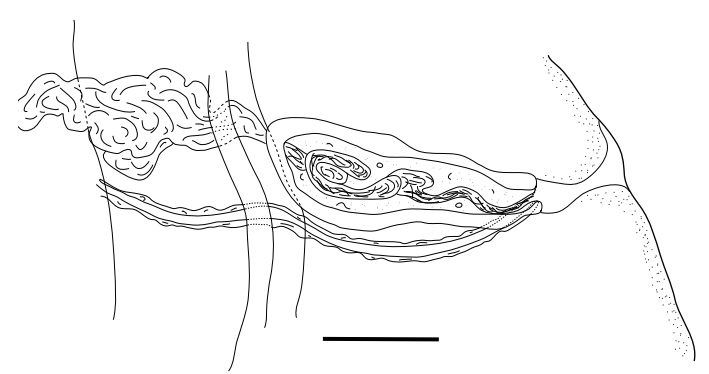

16

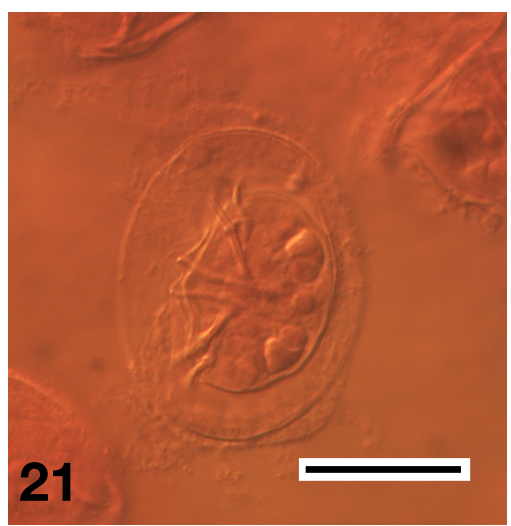

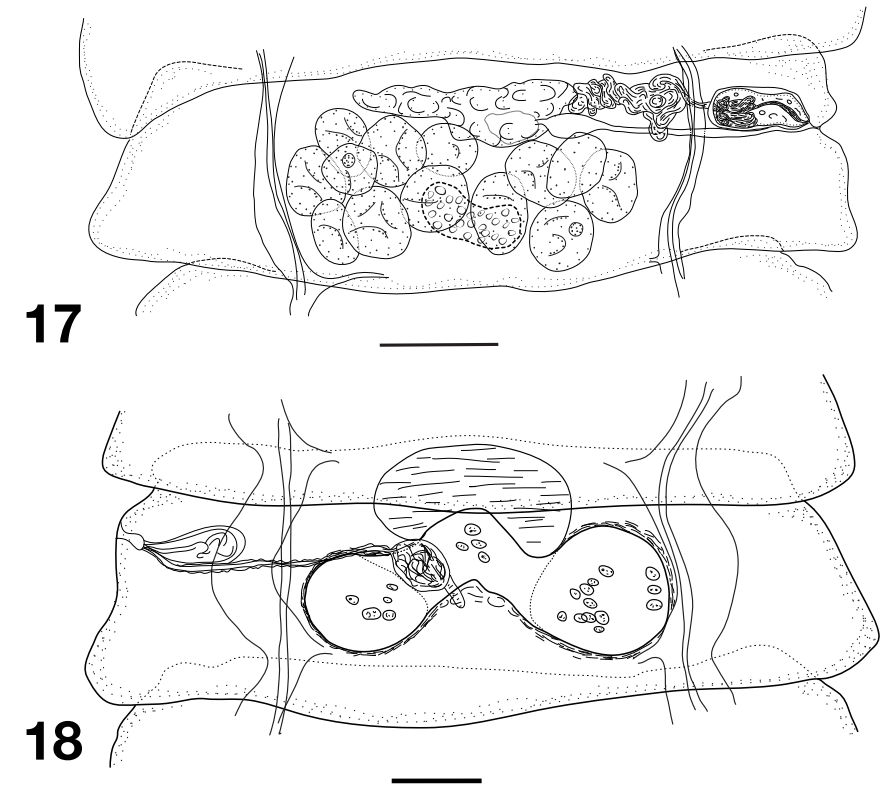

19
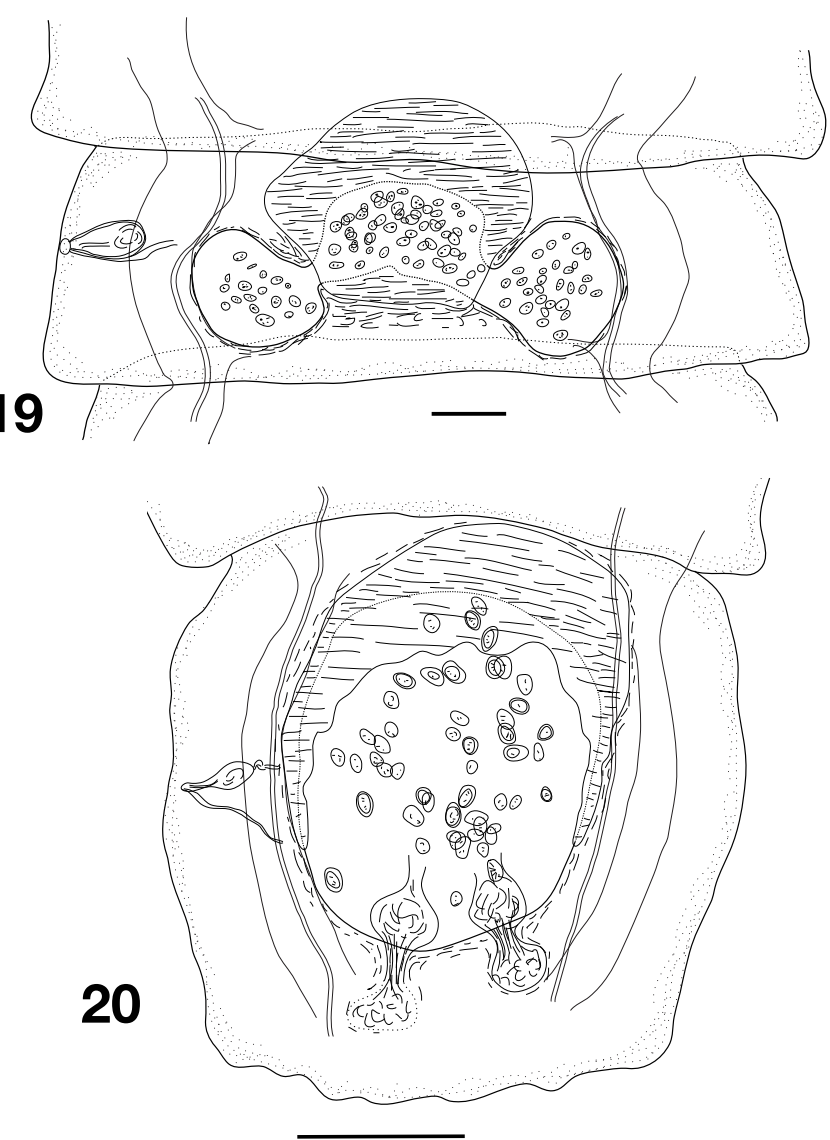

Figs 14-21. Biuterina jensenae sp. nov. 14. Scolex. 15. Rostellar hooks (I: anterior; II: posterior; a: from holotype; b: from Tricholestes criniger (Blyth, 1845)). 16. Cirrus-sac. 17. Mature proglottis, dorsal view. 18-20. Various stages of paruterine organ development. 21. Egg. Scale bars: 14, 17-19=100 $\mu \mathrm{m}$; $15=10 \mu \mathrm{m} ; 16=50 \mu \mathrm{m} ; 20=250 \mu \mathrm{m} ; 21=20 \mu \mathrm{m}$. 
The differences listed above, together with clearly different hosts and distributions lead us to place our material in a new species that we name Biuterina jensenae sp. nov.

We are well aware that, ideally, more material would be desirable to describe this species. However, given the unambiguous characters considered and the fact that access to these parasites is extremely scarce, we think it is worth taking the opportunity to describe and name it, even if additional information, especially concerning the variability of the metrical data, is to be provided when more specimens are available.

Specimens from T. criniger are juvenile and therefore not included in the type series. Their observable characters, especially the shape and organization of their rostellum and hooks, are, however, very similar to those of $B$. jensenae sp. nov. Unless access to fully developed specimens shows otherwise in the future, we consider them conspecific.

\section{Biuterina (?) sp. 1}

\section{Material examined}

MALAYSIA - 2 specs (juveniles, no strobilar anatomy); Selangor, University of Malaya's Gombak Field Station; $3.32^{\circ}$ N, $101.77^{\circ}$ E; 280-350 m a.s.1.; 30 Jul. 2010; MHNG-PLAT-120686.

\section{Host}

Pycnonotus brunneus Blyth, 1845 (Passeriformes, Pycnonotidae).

\section{Remarks}

The hook arrangement in two rows, as well as their triangular shape and epiphyses on both guard and handles, are reminiscent of the genus Biuterina. If confirmed, the combination of numerous (about 60 in number) and very small triangular hooks of same shape and size (about 14) in both rows, would be unique for this genus (Georgiev \& Mariaux 2007).

\section{Biuterina (?) sp. 2}

\section{Material examined}

MALAYSIA -1 incomplete specimen (terminating with a few early mature proglottides); Selangor, University of Malaya's Gombak Field Station; $3.32^{\circ}$ N, $101.77^{\circ}$ E; $280-350$ m a.s.1.; 31 Jul. 2010; partial COI sequence, Genbank MN590288; MHNG-PLAT-120689.

\section{Host}

Alophoixus bres (Lesson, 1832) (Passeriformes, Pycnonotidae).

\section{Remarks}

This worm also shows characters of the genus Biuterina, although the lack of gravid proglottides does not allow a definitive identification. Scolex 325 in diameter. Suckers strong, 162-165 in diameter. Rostellum muscular, 120 in diameter, armed with double crown of 38 typical triangular hooks. Hooks about 15-16 long in both rows, those from first row slightly less massive. Genital pores irregularly alternating, opening slightly anteriorly to middle of lateral proglottis margin. Genital ducts passing between excretory canals. Testes in one continuous posterior field, 7-10 in number. Cirrus pouch elongate, regular, with strong walls, $74-84 \times 28-34(80 \times 30, n=7)$, not reaching or just reaching poral osmoregulatory canals. Vagina posterior to cirrus-sac. As for Biuterina sp. 1, the combination of number/length of rostellar hooks of this specimen seems to have not been observed in the presently known species of Biuterina (see Georgiev \& Mariaux 2007). It is similar to B. jensenae sp. nov. and 
found in the same host family, but shows fewer rostellar hooks, slightly fewer testes and a shorter cirrussac. It is considered here a different taxon to be described when more abundant material is available.

Family Davaineidae Braun, 1900

Genus Raillietina Fuhrmann, 1920

Raillietina hymenolepidoides sp. nov. urn:lsid:zoobank.org:act:0E5860D5-3EAA-4F26-8F0D-DF5ED3718219

Figs 22-26, Table 2

\section{Etymology}

The species name refers to the overall similarity of the strobilar anatomy of this species to that of cestodes of the family Hymenolepididae.

\section{Material examined}

Holotype

MALAYSIA • Selangor, University of Malaya's Gombak Field Station; $3.32^{\circ} \mathrm{N}, 101.77^{\circ} \mathrm{E} ; 280-350 \mathrm{~m}$ a.s.1.; 1 Aug. 2010; MHNG-PLAT-120869.

\section{Paratypes}

MALAYSIA • 2 specs; same collection data as for holotype; MHNG-PLAT-120870.

\section{Hologenophore}

MHNG-PLAT-120869. Partial COI sequence, Genbank MN590290. Additional sequence: MHNGPLAT-130033. Partial COI sequence, Genbank MN590289.

\section{Comparative material}

PHILLIPINES - holotype and two paratypes of Raillietina palawanensis Deardorff, Schmidt \& Kuntz, 1976 from Chalcophaps indica (Linnaeus, 1758) (Columbiformes, Columbidae); Palawan Island; MayJun. 1962; NHM 1369066, 1369067.

\section{Type host}

Chalcophaps indica (Linnaeus, 1758) (Columbiformes, Columbidae).

\section{Prevalence}

$50 \%(2 / 4)$.

\section{Description}

Body very thin and fragile, of medium size; maximum length $55 \mathrm{~mm}$, width mostly 150-350 along entire length of worm, reaching maximum of 425 at level of gravid proglottides; consisting of up to 800 proglottides. Proglottides craspedote, always wider than long except for very last gravid ones; detached gravid proglottides may be almost spherical. Scolex very small, well-delineated from neck, 100-137 $(122, \mathrm{n}=3)$ in diameter. Suckers rounded, $34-43(39.5, \mathrm{n}=10)$ in diameter, muscular, armed with 4-5 dense rows of hooklets, 6-8 in length (Fig. 22b). Rostellar sac absent. Rostellum discoid, 46-69 (61, $\mathrm{n}=3$ ) in diameter, muscular, armed with double row of 150-160 small typical davaineid hooks of length 7-8 (Figs 22a, 23). Pseudoproboscis armed with clearly visible minute accessory spines on about 50 of length (Fig. 22c). Neck well-marked, narrow, 50 in diameter; followed by a long unsegmented section. Proglottization distinct at about $2.5 \mathrm{~mm}$ from posterior margin of suckers. Genital pores unilateral, situated slightly anteriorly to mid-length of lateral proglottis margin. Ventral osmoregulatory canals up to 40 wide, connected posteriorly in each proglottis by transverse anastomosis. Dorsal osmoregulatory 

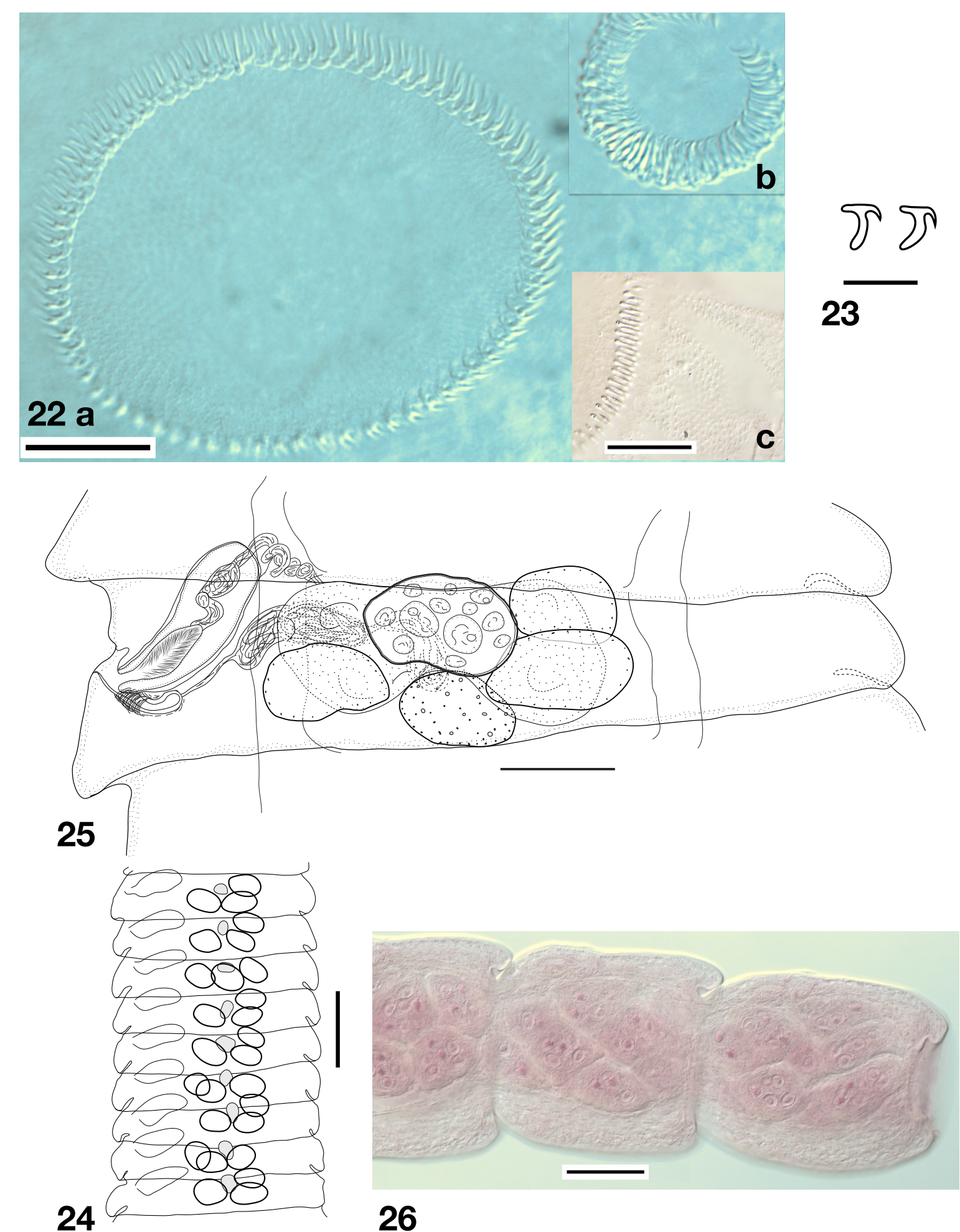

\section{6}

Figs 22-26. Raillietina hymenolepidoides sp. nov. 22. a) Complete rostellar crown. b) Hooklets of sucker. c) Apical tegument with spiniform microtriches. 23. Rostellar hooks. 24. Sketch of male proglottides showing relative position of testes. 25. Early pregravid proglottis, dorsal view. 26. Gravid proglottides with developed capsules. Scale bars: $22=20 \mu \mathrm{m} ; 23=10 \mu \mathrm{m} ; 24,26=100 \mu \mathrm{m} ; 25=50 \mu \mathrm{m}$. 
canals absent. Genital ducts dorsal to ventral osmoregulatory canals. Genital atrium small, 7-13 $\times 9-21$ $(9 \times 14, \mathrm{n}=21)$, infundibular, with wide orifice.

Testes 3 in number; most commonly in triangle, 2 posterior and 1 anterior antiporal, but with frequent variations, sometimes more or less in posterior line, partially overlapping each other (Fig. 24); slightly oval, 35-50 in maximal diameter $(43, \mathrm{n}=33)$. External vas deferens short and making only few coils antero-laterally to proximal end of cirrus-sac. Cirrus-sac elongate, $63-81 \times 28-39(74 \times 34, \mathrm{n}=22)$, straight, with strong wall, reaching osmoregulatory canals, rarely crossing them (Fig. 25); proximal extremity of cirrus-sac often directed anteriorly, positioning cirrus-sac almost parallel to proglottis lateral margin. Internal vas deferens forming a few coils and distinctive proximal dilatation resembling internal seminal vesicle. Cirrus armed with dense long setae.

Vitellarium posterior, central, compact, $26-35 \times 17-26(30 \times 21, \mathrm{n}=14)$. Ovary antero-central, transversely elongate, bilobed, compact and becoming massive, dumbbell-shaped. Mehlis' gland anterior to vitellarium. Vagina opens posterior to male pore, copulatory part 25-48 $\times 6-15(36 \times 12, \mathrm{n}=15)$, with strong walls, surrounded by a large but discrete muscular sphincter (Fig. 25). Proximal (conductive) part of vagina straight, thin, without cellular sleeve, with length similar to that of copulatory part; parallel to posterior wall of cirrus sac; connected with seminal receptacle in lateral field of proglottis. Seminal receptacle slightly convoluted, tubular, crossing poral osmoregulatory canal, poral to ovary.

Uterus starts its development in late mature proglottides as a small antero-dorsal and central sac; with further development, turning into transverse sac filled with large developing eggs; confined in median field. Uterus eventually forming $8-12(10, \mathrm{n}=13)$ egg capsules situated in 2 layers, each one containing 5-10 eggs $(7, n=30)$ (Fig. 26), occasionally overlapping excretory canals. Eggs often, but not always, developing at different rates, possibly leading to the simultaneous presence of fully developed eggs together with others at diverse stages of development within a single capsule. Eggs globular, 32-39.5 $(36.5, \mathrm{n}=27)$. Oncospheres round to oval, $12-14(13, \mathrm{n}=20)$ along longest axis. Embryonic hooks subequal, $5.5-7(6, \mathrm{n}=12)$ in length.

\section{Remarks}

Columbiformes are second only to Galliformes as hosts for cestodes of the genus Raillietina. Over 60 species of these worms have been reported from pigeons and doves (Movsessian 2003a), three of them in Malaysia (Amin-Babjee \& Lee 1992; Lee et al. 1998). In addition, R. palawanensis Deardorff, Schmidt \& Kuntz, 1976 was described by Deardorff et al. (1976) in C. indica in the Philippines. To our knowledge, no other species have subsequently been described from these hosts.

Our material is quite unique in having an extremely reduced and constant number of testes per proglottis and can thus easily be differentiated from all these taxa. Although the number of testes is very variable among species of Raillietina, only a very few have fewer than 5, and none has 3 as observed in our specimens. Two species, $R$. palawanensis and $R$. quadritesticulata Moghe, 1925, are nevertheless relatively similar, though not identical, to our material for this character (3-4 and 4 testes, respectively, according to their descriptions). We reexamined part of the $R$. palawanensis type series, including its holotype, and although several original observations in Deardorff et al. (1976) are confirmed, we also observed several significant differences (Table 2):

- the worms are much longer (length more than $60 \mathrm{~mm}$, complete specimen probably more than $100 \mathrm{~mm}$ long) and wider (up to 790 at level of gravid proglottides);

- the dorsal osmoregulatory canals are absent (likely mistaken for longitudinal muscle bundles in the original description); 
Table 2. Main morphological characteristics of Raillietina hymenolepidoides sp. nov. and closely similar taxa. * New values from our observations of type material. Abbreviations: $\mathrm{L}=$ Length; $\mathrm{W}=$ Width; $\varnothing=$ Diameter.

\begin{tabular}{|c|c|c|c|}
\hline & R. hymenolepidoides & R. palawanensis & R. quadritesticulata \\
\hline Reference & Present study & Deardorff et al. (1976) & Moghe (1925) \\
\hline Host & Chalcophaps indica & Chalcophaps indica & Streptopelia tranquebarica \\
\hline Ditribution & Malaysia & Philippines & India \\
\hline $\mathrm{L}[\mathrm{mm}] \times \mathrm{W}$ & $55 \times 425$ & $*>60 \times * 790$ & $62-137 \times 924-1230$ \\
\hline \# proglottides & $800+$ & - & 188-196 \\
\hline Scolex $\varnothing$ & $100-137$ & $300-320$ & 165 \\
\hline Sucker ø & $34-43$ & $72-76$ & $52-54 \times 35-40$ \\
\hline Rostellum ø (× L) & $46-69$ & $125-170 \times 110-160$ & 96 \\
\hline \# hooks & $150-160$ & 108 & 180 \\
\hline L hooks & $7-8$ & $20-24$ & 6 \\
\hline L neck [mm] & 2.5 & $1.5-2.8$ & 1 \\
\hline Dorsal canals & Absent & *Absent & Present (?) \\
\hline Atrium $\mathrm{L}[\mathrm{mm}] \times \mathrm{W}$ & $7-13 \times 9-21$ & $6-15 \times 7-26$ & - \\
\hline Testes number & 3 & *(3)-4-5-(6) & 4 \\
\hline Testes $\varnothing$ & $35-50$ & $45-57$ & $68-75 \times 75-77$ \\
\hline Cirrus sac $(\mathrm{L} \times \mathrm{W})$ & $63-81 \times 28-39$ & $93-* 120 \times 28-* 56$ & $138 \times 68$ \\
\hline Copulatory vagina $(\mathrm{L} \times \mathrm{W})$ & $25-48 \times 6-15$ & *39-52 × 10-17 & $108 \times 32$ \\
\hline Vitellarium $(\mathrm{L} \times \mathrm{W})$ & $26-35 \times 17-26$ & $25 \times 30$ & - \\
\hline \# egg capsules & $8-12$ & $10-* 17$ & $40-50$ \\
\hline Eggs per capsule & $5-10$ & $4-* 7$ & $6-8$ \\
\hline \# oncospheres & $12-14$ & *16-18 & $18 \times 16$ \\
\hline
\end{tabular}

- testis number is essentially 4 (5 is not unusual, 3 and 6 are very rare); it should be noted that the initial development of testes is not synchronous, with one, sometimes two, antiporal testes showing a delayed growth;

- the cirrus sac may be slightly larger than reported (up to 120 in length and 56 in width);

- the copulatory vagina part is longer (39-52);

- up to 17 egg capsules per proglottis, each containing up to 7 eggs can be observed in gravid proglottides;

- oncospheres are 16-18 in diameter.

These observations confirm that $R$. palawanensis differs from our material by having a larger scolex and rostellum and fewer, much larger, rostellar hooks, as well as a larger cirrus-sac, while $R$. quadritesticulata has more rostellar hooks, a larger cirrus-sac and more egg-capsules per proglottis (Table 2). Our material is therefore clearly distinct and we place it in a new species, Raillietina hymenolepidoides sp. nov. 
Interestingly, all three species with an extreme reduction of testis number are found in South/South East Asia and two in the same host species. Although this clearly suggests a close relationship between these taxa, the significance of this observation in a phylogenetic context remains to be studied. A similar reduction in testis number is observed in the genus Diorchiraillietina Yamaguti, 1959, whose single species has only 2 testes per segment. It is found in various pangolin species in Africa and South Asia, including in species distributed in Malaysia, and may be indicative of a host-switching event. Molecular samples from pangolin parasites would allow the examination of this hypothesis.

The absence of dorsal excretory canals is an uncommon feature found in some davaineids. It is observed in the monotypic genera Porogynia Railliet \& Henry, 1909 and Baerfainia Yamaguti, 1959. The latter, found in African Pholidota and erected for Raillietina anoplocephaloides Baer \& Fain, 1955 (Yamaguti 1959), shows a similar reduction of testis numbers (4, sometimes 3 ) as observed in our material. Its rudimentary rostellum and particular vagina structure are, however, very different.

Raillietina mahnerti sp. nov.

urn:lsid:zoobank.org:act:0705D781-68CD-4B0B-BF6B-0E8DAF4A24EF

Figs $27-30$

\section{Etymology}

The species is dedicated to Prof. Volker Mahnert, former director of the Museum of Natural History of Geneva and eminent naturalist (Schwendinger 2019), who passed away during the preparation of this paper.

\section{Material examined}

Holotype

MALAYSIA • Selangor, University of Malaya's Gombak Field Station; $3.32^{\circ} \mathrm{N}, 101.77^{\circ} \mathrm{E} ; 280-350 \mathrm{~m}$ a.s.1.; 5 Aug. 2010; MHNG-PLAT-121344.

\section{Paratypes}

MALAYSIA • 4 specs; same collection data as for holotype; MHNG-PLAT-121347.

Hologenophore

MHNG-PLAT-121346. Partial COI sequence, Genbank MN590291.

\section{Type host}

Chalcophaps indica (Linnaeus, 1758) (Columbiformes, Columbidae).

\section{Prevalence}

$25 \%(1 / 4)$.

\section{Description}

Thin and very long worm with body consisting of more than 850 proglottides, reaching ca $200 \mathrm{~mm}$ in length (estimated from fragments) and 950 in maximum width at level of pregravid proglottides. Proglottides weakly craspedote, wider than long, except for the very last gravid ones. Scolex not clearly delineated from neck, 185 in diameter. Suckers round, 46-50 $(49, \mathrm{n}=4)$ in diameter; muscular, armed with 6 dense rows of hooklets 3-6 long; crown of hooklets progressively reduced in posterior direction, then interrupted (Fig. 27b). Rostellum discoid, 100 in diameter, 60 long, weakly muscular, armed with double crown of about 270 hooks (Fig. 27a). Rostellar hooks of typical davaineid shape, delicate, 9 long 
(Fig. 27c). Pseudoproboscis covered with minute, spine-like microtriches. Neck segmentation distinct at $1.3 \mathrm{~mm}$ from posterior margin of suckers. Genital primordia appearing at about $200^{\text {th }}$ proglottis. Genital pores unilateral, situated at $35 \%$ of lateral proglottis margin. Ventral osmoregulatory canals up to 58 wide, connected posteriorly in each proglottis by wide transverse (occasionally bifurcated) anastomosis. Dorsal osmoregulatory canals 1-2 wide; not distinct in many proglottides. Genital ducts passing between osmoregulatory canals (or dorsal to ventral canals when dorsal canal not distinct). Genital atrium small, infundibular, inconspicuous.

Testes $8-14$ in number $(11, \mathrm{n}=75)$, in single layer; in two fields, each with variable number of testes: poral group of 1-6 testes and larger antiporal group of 5-10 testes (average 4 and 7, respectively, $n=75$ ), one detached testis sometimes positioned posteriorly; testes round, in single layer (Fig. 28). External vas deferens highly convoluted, extended transversely almost up to middle of proglottis. Cirrus-sac elongate, oval, with well-marked walls, 90-115 $\times 44-58(102 \times 49, \mathrm{n}=45)$, not reaching osmoregulatory canals. Internal vas deferens short, making single loop before reaching rounded expansion resembling internal seminal vesicle, $19-26(22, \mathrm{n}=20)$ in diameter. Cirrus armed with dense long setae, connected to sac by distinct retractor muscles (Fig. 29).

Vitellarium posterior, central, compact and globular, 50-75 $(62, \mathrm{n}=26)$. Ovary antero-central, compact fan-shaped, composed of a few large lobes. Mehlis' gland just anterior to vitellarium. Seminal receptacle tubular, more distinct in pregravid proglottides. Vagina opened posteriorly to male pore, composed of a copulatory part $40-48 \times 8-15(44 \times 11, \mathrm{n}=12)$, surrounded by a well-defined and thick wall, terminally surrounded by discrete but wide muscular sphincter, followed by short and narrow proximal (conductive) part and wider elongate seminal receptacle extending transversely, then posteriorly toward mid-proglottis (Figs 28-29).

Eggs developing in well-defined parenchymatous capsules. Capsules 19-31 $(26, \mathrm{n}=34)$ in number per proglottis, 80-120 $(95, \mathrm{n}=20)$ in diameter, each containing 4-10 $(6, \mathrm{n}=85)$ eggs (Fig. 30). Eggs 26-35 $(31, \mathrm{n}=20)$ in diameter, oncospheres $14-19(16, \mathrm{n}=24)$ in diameter, embryonic hooks $6-8(7, \mathrm{n}=10)$ long.

\section{Remarks}

With its typical rostellar apparatus and hammer-shaped hooks, armed suckers, unilateral genital pores and multiple egg capsules, this material can confidently be placed in the genus Raillietina. As stated above, over 60 species of this genus are known from Columbiformes worldwide (Movsessian 2003a). In order to check whether our material belongs to any of them, we initially compared the number and size of rostellar hooks as well as the number of testes with our observations, allowing the differentiation of most of these species from the present material. The few remaining species listed below are more similar to our material and are compared in more detail.

Railletina flaminiata (Meggitt, 1931) (usually erroneously reported as R. flaminata) was described from Columba punicea Blyth, 1842 and Goura coronata (= G. cristata (Pallas, 1764)) in Myanmar (Meggitt 1931). The former host is also present in Malaysia. The species description is incomplete, in particular as the number of rostellar hooks is lacking, but most available characters are similar to our observations. However, the number of testes (5-9) is somewhat smaller and the number of egg capsules (16) and eggs per capsule (2-6 but mostly 2$)$ are distinctive.

Raillietina kunisakiensis Sawada \& Kugi, 1979 is known from Treron sieboldii sieboldii (Temminck, 1835) in Japan, a host that is absent from the Malaysian Peninsula. Its description makes it very similar to our material, but it has longer (14) rostellar hooks, a slightly different disposition and number of testes and a vagina that is not split into distinct copulatory and conductive parts (Sawada \& Kugi 1979). 

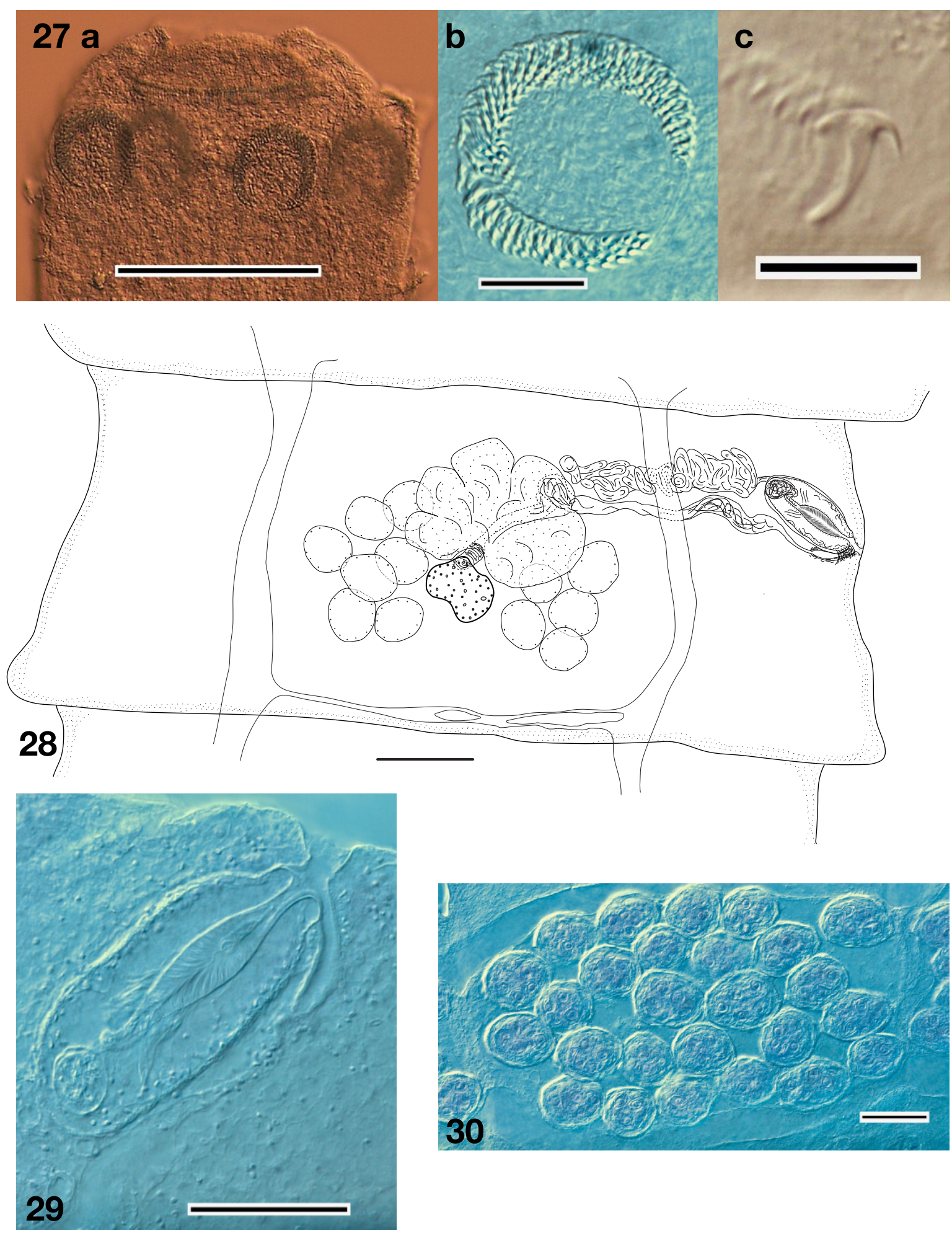

Figs 27-30. Raillietina mahnerti sp. nov. 27. a) Scolex. b) Sucker hooklets. c) Rostellar hook. 28. Mature proglottis, ventral view. 29. Copulatory organs. 30. Gravid proglottis with egg capsules. Scale bars: $27 \mathrm{a}$, $28,30=100 \mu \mathrm{m} ; 27 \mathrm{~b}=20 \mu \mathrm{m} ; 27 \mathrm{c}=10 \mu \mathrm{m} ; 29=50 \mu \mathrm{m}$. 
Raillietina fuhrmanni idiogenoides (Baer, 1933) is known from various African Columbidae. According to Mahon (1958), it has slightly fewer (230) rostellar hooks than in our material and a longer (145-164) cirrus sac.

Raillietina joyeuxbaeri (Nguyen Thi Ky \& Dubinina, 1980) is a parasite of Streptopelia tranquebarica (Hermann, 1804) in Vietnam (the host has been introduced to Malaysia), showing close similarity to our material. However, it is a smaller species with slightly larger (11-13) rostellar hooks and fewer testes $(6-7)$.

Finally, we also consider Raillietina polychalix (Kotlan, 1921) here. Although this species is parasitic in Psittaciformes, it was also reported in Columba livia by Movsessian (2003a) (however, no source is cited). This species is very similar to our material for most characters, including a close (240-250) number of rostellar hooks, which are, however, somewhat longer (13). It also has a slightly longer cirrus-sac (120) and wider scolex (320).

Even though morphological identification of Raillietina is notoriously difficult, we consider that the differences listed above, together with its new host and locality, are sufficient to conclude that our material differs from all know species of Raillietina and to place it in a new species, $R$. mahnerti sp. nov.

Raillietina (sensu lato) sp.

\section{Material examined}

MALAYSIA • 1 juv.; Selangor, University of Malaya's Gombak Field Station; $3.32^{\circ}$ N, $101.77^{\circ}$ E; 280-350 m a.s.1.: 5 Aug. 2010; no molecular voucher; MHNG-PLAT-121159.

\section{Host}

Tricholestes criniger (Blyth, 1845) (Passeriformes, Pycnonotidae).

\section{Description}

This material is distinct from other davaineid species described in this work. Scolex Raillietina-like, 215 in diameter; large suckers, $135-145(139, \mathrm{n}=4)$ in diameter, armed with 8 rows of hooklets, $10-13$ long; rostellum 92 in diameter and 89 long, bearing ca 110 hooks in two rows, anterior row 17-19 long, posterior row 16-18 long. Genital pores unilateral. Early male proglottides containing 17-23 testes.

\section{Remarks}

The combination of hook characteristics observed in our material is uncommon and has almot never been reported in Raillietina (s. lat.) (Artiukh 1966; Movsessian 2003a). Interestingly, the single species with overlapping characters is Paroniella pycnonoti (Yamaguti \& Mitunaga, 1943) found in Pycnonotus sinensis formosae Hartert, 1910 in Taiwan.

However, although the original description of Yamaguti \& Mitunaga (1943) was correctly summarized by Artiukh (1966) and Movsessian (2003a), these authors failed to notice that in the original description the number of rostellar hooks was described as "... arranged in two alternating circles of 105-115 each". The total number of hooks in P. pycnonoti should thus be $210-230$ in total, a figure different from what we observed in our material, which remains an unidentified species, either in Raillietina or Paroniella. 
Genus Ophryocotyloides Fuhrmann, 1920

Ophryocotyloides dasi Tandan \& Singh, 1964

Figs 31-32

\section{Material examined}

MALAYSIA • 1 spec.; Selangor, University of Malaya's Gombak Field Station; $3.32^{\circ} \mathrm{N}, 101.77^{\circ}$ E; 280-350 m a.s.1.; 4 Aug. 2010; partial COI sequence, Genbank MN590292; MHNG-PLAT-121155.

\section{Host}

Psilopogon henricii (Temminck, 1831) (Piciformes, Ramphastidae; also placed in Megalaimidae).

\section{Description}

Strong worm with body of medium size, $74 \mathrm{~mm}$ long; maximum width $2.9 \mathrm{~mm}$ at level of gravid proglottides; strobila consisting of 302 proglottides. Proglottides weakly craspedote, always wider than long. Scolex 375 in diameter, separated from strobila by a well-marked constriction. Suckers round to oval, 180-190 $(184, \mathrm{n}=4)$ in diameter; muscular, armed with about 10 dense rows of hooklets, approximately 11-13 in length. Rostellar sac absent, rostellum discoid, 175 in diameter, 90 long, glandular, with weak surrounding muscular layers, armed with two rows of hooks. Hooks 230 in number, with typical davaineid shape, 15.5-16.5 long in both rows. Apical extremity of scolex (pseudoproboscis) tegument covered by distinct minute spines (Fig. 32). Neck 175 in diameter; first proglottides distinct at $1 \mathrm{~mm}$ behind posterior margin of suckers. Genital pores unilateral, situated at $20-25 \%$ of lateral proglottis margin. Ventral osmoregulatory canals up to 45 wide, connected posteriorly in each proglottis by transverse anastomosis. Dorsal osmoregulatory canals 5-12 wide, connected posteriorly by transverse anastomosis in some proglottides. Genital ducts passing between osmoregulatory canals. Genital atrium regular, inconspicuous, $18-25$ deep and 12-20 in diameter.

Testes 30-40 in number $(34, \mathrm{n}=17)$; in 2 unequal fields, one poral consisting of 5-9 testes and one larger antiporal, consisting of 22-31 units ( 7 and 26, respectively, $n=17)$; testes rounded, in 2 layers, sometimes in 3 layers antiporally; a few of them may overlap some ovarian lobes. External vas deferens well-marked and oriented transversely, making many loops around a straight line, becoming wider centrally, up to 40 in diameter. Cirrus-sac pear-shaped, thick-walled, with short narrower distal part, almost globular, $120-135 \times 68-78(125 \times 72, \mathrm{n}=18)$, not reaching osmoregulatory canals (Fig. 33). Internal vas deferens $17-25$ in diameter, forming a few large coils. Cirrus unarmed.

Vitellarium posterior, central, transversely elongate, compact, with irregular shape, 85-120 $\times 140-220$ $(103 \times 189, \mathrm{n}=12)$. Ovary antero-central, fan-shaped, deeply lobated, becoming more massive in advanced mature proglottides. Mehlis' gland anterior to vitellarium. Seminal receptacle poorly marked, elongate, poral. Vagina opened posteriorly to male pore, straight, surrounded in its distal part by a welldeveloped sheath of large cells, forming small dilation behind cirrus-sac.

Egg developing in entire proglottis, including external to osmoregulatory canals. Uterus apparently saccular although barely visible, no egg capsules. Oncospheres small but no fully-developed eggs observed, as last proglottides in our specimen are filled with calcareous corpuscles.

\section{Remarks}

With numerous typical davaineid hooks in 2 rows, armed suckers, unilateral genital pores and an absence of egg capsules, our material belongs to the genus Ophryocotyloides Fuhrmann, 1920. According to Movsessian (2003b), 6 species of this genus parasitize Piciformes and 3 are found in the genus Psilopogon. All of them have been described from India and show very similar characters. 


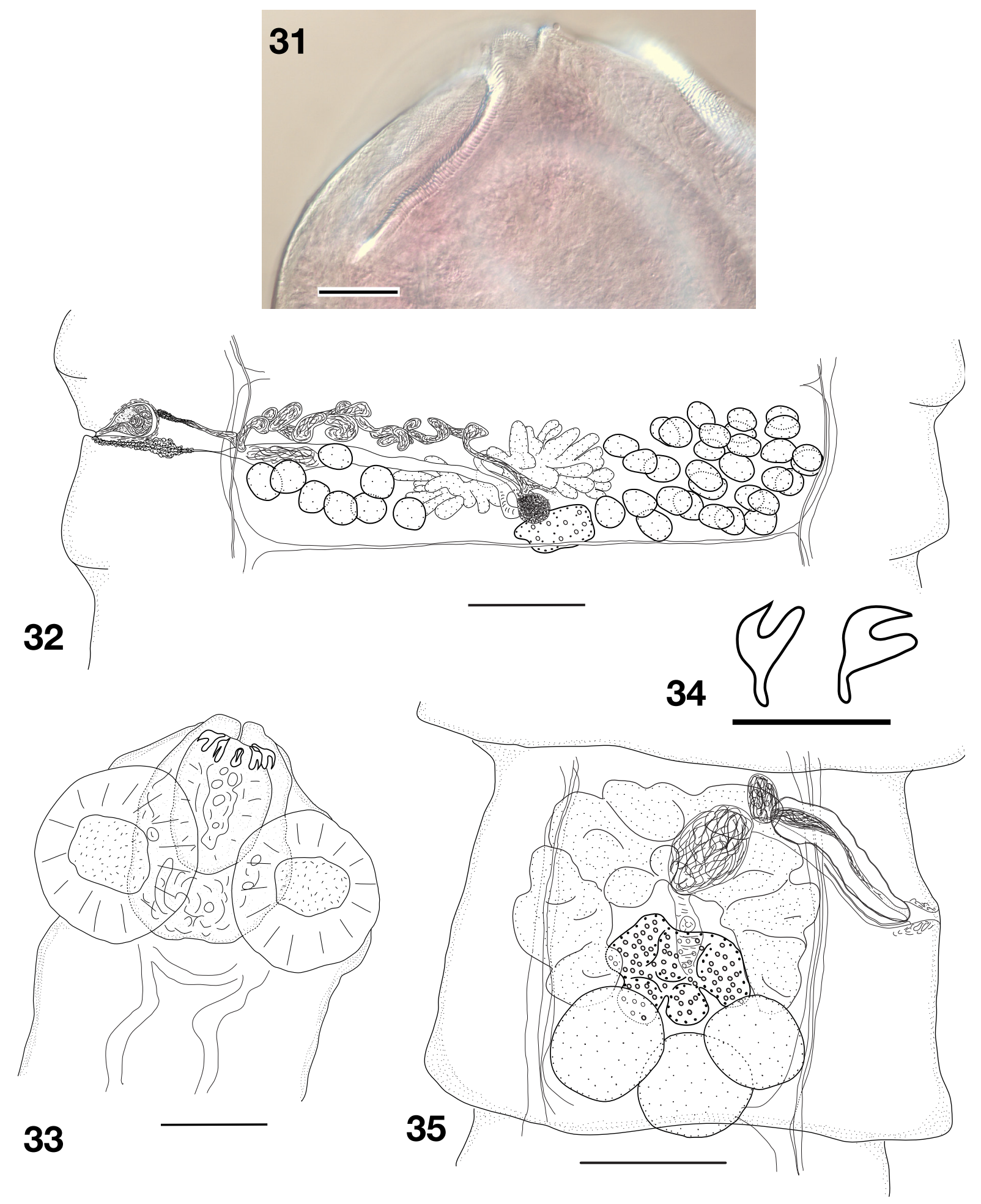

Figs 31-35. - 31-32. Ophryocotlyoides dasi Tandan \& Singh, 1964. 31. Scolex with double crown of hooks, spinuous pseudoproboscis and armed suckers margins. 32. Mature proglottis, ventral view. 33-35. Variolepis cf. bilharzii (Krabbe, 1869). 33. Scolex. 34. Rostellar hooks. 35. Mature proglottis. Scale bars: $31,33=50 \mu \mathrm{m} ; 32=250 \mu \mathrm{m} ; 34=20 \mu \mathrm{m} ; 35=100 \mu \mathrm{m}$. 
Ophryocotyloides barbeti Singh, 1959 was described from the Brown-headed Barbet, P. zeylanicus (Gmelin, 1788) and O. haemacephala Singh, 1959 from the Coppersmith Barbet, P. haemacephalus (Muller, 1776). The former taxon can easily be differentiated from our material by its smaller number (150) of longer (22-27) hooks and higher number (10-15) of poral testes. The latter resembles our specimen but has a smaller rostellum (110-160); although the total numbers of testes are comparable, it has a larger poral number of testes according to Singh's (1959) drawing.

The third species, $O$. dasi Tandan \& Singh, 1964 described from P. haemacephalus, is the most similar to our material on the basis of the description by Tandan \& Singh (1964). It only differs in minor details like smaller suckers, which are reported to only bear 6-7 rows of hooklets. Ophryocotyloides dasi is also described with slightly fewer aporal testes (17-21), although the total number just overlaps our own observations. This is not sufficient to differentiate this species from our material with any certainty, as superimposed aporal testes are difficult to differentiate. Finally, Tandan \& Singh (1964) reported a vaginal sphincter that is not present in our material (unless they refer to the cellular sheath we have observed). All other characters closely match our measurements. Without access to the type specimens of $O$. dasi, we consider that the minor differences noted above are not sufficient to distinguish our specimen from this species. In addition, it should be noted that the host of $O$. dasi and the Yellowcrowned Barbet (in which we found our material) have overlapping geographical ranges. This is the first report of this taxon since its original description. $P$. henricii is a new host for this species, and this is the first record of $O$. dasi in SE Asia.

Family Hymenolepididae Perrier, 1897

Genus Variolepis Spasskii \& Spasskaya, 1954

Variolepis cf. bilharzii (Krabbe, 1869)

Figs 33-35, Table 3

\section{Material examined}

MALAYSIA - 1 spec.; Selangor, University of Malaya's Gombak Field Station; 3.32 ${ }^{\circ}$ N, $101.77^{\circ}$ E; 280-350 m a.s.1.; 2 Aug. 2010; partial COI sequence, Genbank MN590293; MHNG-PLAT-121153.

\section{Host}

Copsychus malabaricus (Scopoli, 1786) (Passeriformes, Muscicapidae).

\section{Description}

Worm with body of medium size, $7.5 \mathrm{~mm}$ long; maximum width 380 at level of last available pregravid proglottides. Strobila consisting of 73 proglottides. Proglottides craspedote, wider than long. Scolex poorly delineated from neck, 150 in diameter (Fig. 33). Suckers muscular, rounded, 75-88 (82, n=4) in diameter; base covered with well developed microtriches. Rostellar sac $104 \times 74$, wide, mostly glandular. Rostellum well-developed, $66 \times 45$, muscular, armed with a single row of 10 small cricetoid hooks, about 15 long. Hooks with strong guard and thin, reduced handles (Fig. 34). Neck not well marked, 140 in diameter; proglottization distinct at about 280 behind posterior margin of suckers. Genital pores unilateral, dextral, situated at about $40 \%$ of lateral proglottis margin length. Ventral osmoregulatory canals 8-13 wide, connected posteriorly in each proglottis by transverse anastomosis. Dorsal osmoregulatory canals $4-5$ wide. Genital ducts dorsal to osmoregulatory canals. Genital atrium narrow, 10-15 deep, infundibular, with wide orifice.

Testes 3 in number; large, up to 109 in diameter, situated posteriorly and basically on transverse line, although one or another can be located anterior to the two others. Small external seminal vesicle present, just proximal to cirrus-sac. Cirrus-sac, elongate, $112-134 \times 25-33(124 \times 29, \mathrm{n}=11)$, crossing 
osmoregulatory canals. Discrete internal seminal vesicle present, in proximal quarter of cirrus-sac. Cirrus unarmed.

Vitellarium posterior to ovary, central, massive. Ovary antero-central, bi-winged with wings diverging posteriorly, compact but forming a few lobes in late development. Mehlis' gland anterior to vitellarium. Vagina opened posteriorly to male pore and parallel, postero-ventrally to cirrus pouch. Seminal receptacle central and dorsal, between ovary wings, anterior to vitellarium, up to 74 in largest diameter (Fig. 35).

Uterus starts its development in late mature proglottides as an antero-central sac, developing into a horseshoe-shaped saccular structure. Completely developed uterus and eggs not observed.

\section{Remarks}

Our material most closely matches the definition of Variolepis Spasskii \& Spasskaya, 1954. This genus has been treated very differently by various authors. Notably it has recently been put in synonymy with Wardium Mayhew, 1925 by Czaplinski (in Czaplinski \& Vaucher 1994). This synonymy has, however, been widely considered as unjustified and Variolepis is now recognised as being valid (Mariaux et al. 2017; Dimitrova et al. 2019).

The most widespread species of Variolepis is the type-species, $V$. farciminosa (Goeze, 1782), that has been found on several continents and in a wide diversity of passerine hosts. Most of these contributions report substantial variations in the observed characters (see, e.g., Illescas Gómez \& Gómez García 1984), casting some doubts on their conspecificity and possibly being indicative of a complex of species. A common character of " $V$. farciminosa" s. lat. is nevertheless the presence of relatively long (20 or more) rostellar hooks, that unambiguously differentiate it from our material. Nine more species of the genus are known from Passeriformes worldwide (Schmidt 1986). We have summarized their available distinctive characters in Table 3. Most differ from our material by their larger rostellar hook size and only V. planestici (Mayhew, 1925) and V. bilharzii (Krabbe, 1869) are comparable for that crucial character.

Variolepis planestici was described from an American robin by Mayhew (1925), unfortunately without some crucial details such as rostellar or cirrus-sac measurements. Despite its similar hooks, this species seem to differ from our material by having its testes clearly disposed in a triangle.

The original description of $V$. bilharzii is incomplete; however, Krabbe's drawings show hooks with massive guards that are much longer than the blades (Krabbe 1869: figs 228-229.). A later description by Joyeux \& Baer (in Joyeux et al. 1928) from a West African drongo is the most complete to date but remains partial. The species was subsequently only found again by Johri (1935) in a crow from Myanmar. Interestingly, in his figure 4, Johri illustrates hooks of the same shape as shown by Krabbe. It is difficult to separate our material from $V$. bilharzii, although our specimen has a smaller scolex and suckers and a somewhat larger cirrus-sac. Furthermore $V$. bilharzii is described with testes in a triangular arrangement, but testes are mostly in a row in our material (although some variation is possible, see Fig. 35).

Globally, the characters available to differentiate our material and the two species discussed above are extremely limited and basically insufficient. Previously used arguments (e.g., Mayhew (1925) claimed a slight difference in hook shape for erecting $V$. planestici) need to be critically evaluated with more material. As a consequence, it is very difficult to separate our material from both above-mentioned taxa, or indeed to separate them from each other. For now, we attribute our specimen to $V$. bilharzii, given its species range and diversity of hosts, which include East Asia and Muscicapidae. Due to priority, it is also the name that would apply to all these specimens in case they are eventually considered conspecific. A more definite conclusion would require additional specimens to assess their morphological variation and, 


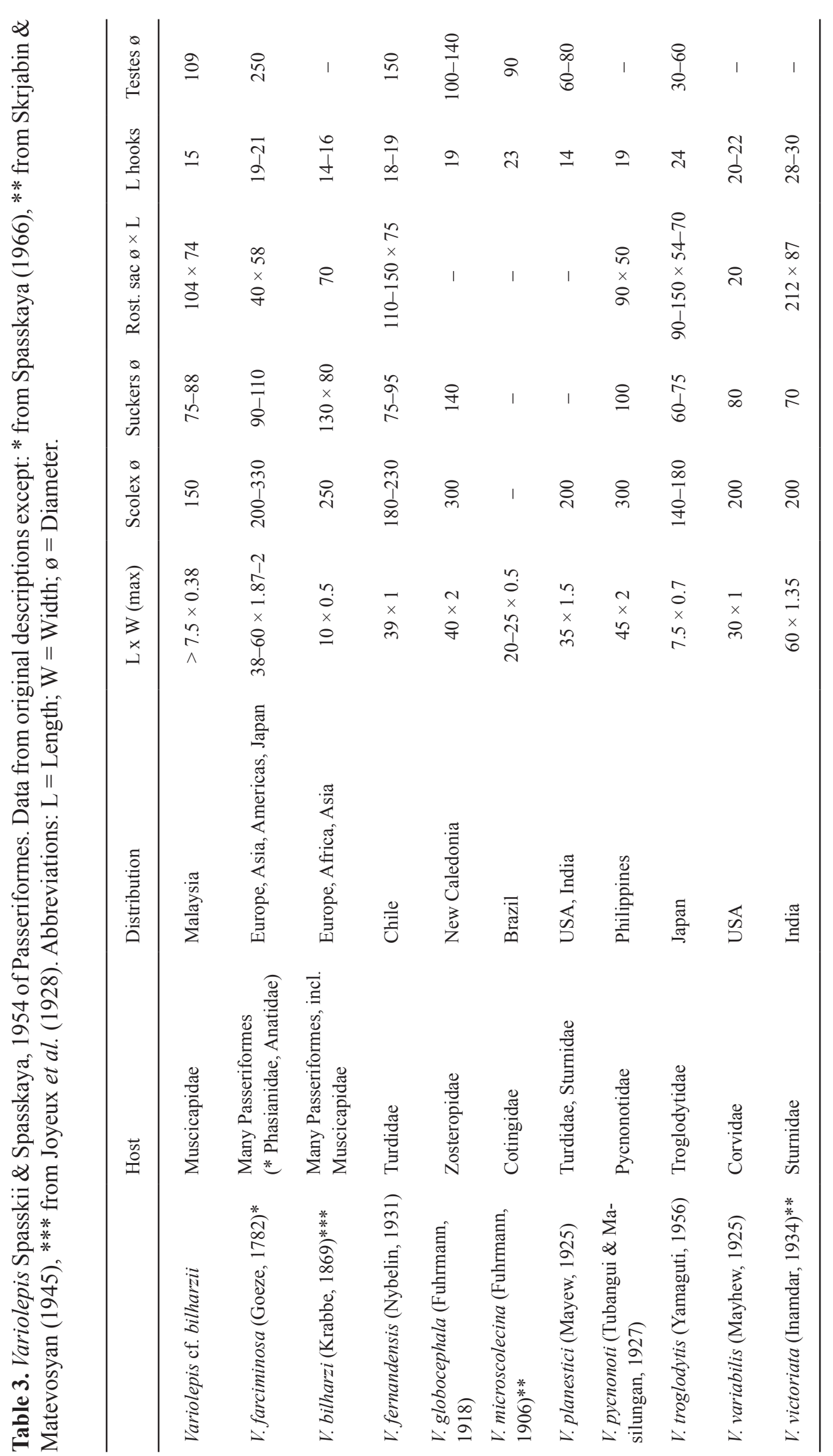


in the case of the Malaysian material, fully gravid proglottides to observe the morphological characters of the eggs.

Family Mesocestoididae Perrier, 1897

Genus Mesocestoides Vaillant, 1863

Mesocestoides sp. (larvae)

\section{Material examined}

MALAYSIA • 6 larval forms (in mesenteries); Selangor, University of Malaya's Gombak Field Station; $3.32^{\circ} \mathrm{N}, 101.77^{\circ} \mathrm{E} ; 280-350$ m a.s.1.; 7 Aug. 2010; partial COI sequence, Genbank MN590294; MHNGPLAT-121160.

\section{Host}

Philentoma pyrhoptera (Temminck, 1836) (Passeriformes, Vangidae).

\section{Remarks}

The presence, possibly massive, of tetrathyridia is known from many avian species, including Passeriformes over almost all the world (Literák et al. 2004; Mariaux et al. 2017; Heneberg et al. 2019). This is a new host and locality for the genus.

\section{Discussion}

The helminth parasitofauna of Malaysian birds, and especially its cestode component, has been very little studied. Surveys are few (e.g., Kuntz (1969) examined over 100 species of birds, but from Malaysian Borneo only) and recent isolated reports mostly deal with the parasitofauna of domestic animals or focusing on other types of parasites, especially ectoparasites, haematozoa or viruses. A few isolated contributions by S. Amin Babjee and C. Lee are an exception, as these authors examined various wild birds belonging to the Corvidae (Amin-Babjee et al. 1987), Phasianidae (Amin-Babjee et al. 1985) and Columbidae (Amin-Babjee \& Lee 1992; Lee et al. 1998). As far as cestodes are concerned, the specific diversity reported in these papers remains, however, extremely limited. In addition, Singh et al. (1987) conducted a survey of vertebrates from the Ulu Endau area (South of Malay Peninsula) but found no (!) endoparasites in 17 species of birds. Some more comprehensive reports focused on 'neighbouring' Myanmar or Sri Lanka birds (e.g., Meggitt 1927, 1931; Johri 1935, 1951; Burt 1940) but are mostly outdated now in terms of degree of detail compared to the recent standards in cestode taxonomy and remain patchy. It is thus no overstatement to consider that the parasitofauna of the over 800 species of birds known from Malaysia is basically unexplored. More generally, Southeast Asia remains one of the large areas in the world where the cestodes of wild animals are particularly poorly known.

Despite the fact that the small size of our sample prevents a detailed analysis of its faunal structure, we observe that all major bird cestode families are represented, most by several taxa. The apparent high diversity of Paruterinidae is especially interesting and further data for this group would allow for useful comparisons with its better known African fauna.

In this contribution we identified 13 taxa, 5 of them new. There is little doubt that most of the others would also represent new species, provided a sufficient number of specimens is available. In fact, we postulate that a systematic study of wild birds would allow the description of dozens of new taxa with limited efforts, even if restricted to a few specimens from common bird species.

Given the particular vulnerability of these hosts (Soh et al. 2006) and a more general rapid disappearance of tropical habitats in Southeast Asia (see, e.g., Sodhi et al. 2010), large scale surveys focusing on 
the parasitofauna of non-model vertebrate hosts, an essential component of global biodiversity, should urgently be undertaken.

\section{Acknowledgements}

We are grateful to Prof. Rosli Hashim and Prof. Rosli Ramli (Kuala Lumpur), as well as to the staff from the University of Malaya's Gombak field station for their efficient and friendly support in organizing our field trip in Malaysia. Dr Andrea Waeschenbach (London) is heartily thanked for sharing unpublished sequence data. We thank Dr Leslie Chisholm (Adelaide) and Dr Anna Phillips (Washington, DC) for providing comparison material, and Dr Scott Gardner (Lincoln, NE) who kindly helped with rare literature. We thank Janik Pralong (Geneva) for the preparation of specimens and Dr Alice Cibois (Geneva) for ornithological advice.

Support from NSF-PBI, USA (awards DEB 0818696 and 0818823 to J.N. Caira and K. Jensen) and from the Natural History Museum of Geneva is acknowledged.

\section{References}

Amin-Babjee S.M. \& Lee C.C. 1992. Parasites of the spotted turtledove (Streptopelia chinensis) in Peninsular Malaysia. Malaysian Applied Biology 21: 93-97.

Amin-Babjee S.M., Lee C.C. \& Krishnasamy M. 1985. A preliminary survey of parasites of Malaysian red jungle fowl (Gallus gallus spadiceus). Kajian Veterinar 17: 141-146.

Amin-Babjee S.M., Lee C.C. \& Mohna S.S. 1987. Parasites of the house crow (Corvus splendens). Jurnal Veterinar Malaysia 5 (1): 59-60.

Artiukh E.S. 1966. Davaineata. Cestodes of wild and domestic animals. In: Skrjabin K.I. (ed.) Principles of Cestodology. Volume 6. Izdatel'stvo Akademii Nauk SSSR, Moscow.

Baer J.G. 1925. Cestodes nouveaux du Sud-Ouest de l'Afrique. Revue suisse de Zoologie 31: 529-548.

Baer J.G. 1956. Parasitic helminths collected in West Greenland. Meddelelser om Grønland 124 (10): $1-55$.

Banerjee S., Manna B. \& Sanyal A.K. 2018. Anonchotaenia adhiraji sp. n. (Platyhelminthes: Cestoidea) from a bird Hypsipetes madagascarensis from Arunachal Pradesh, India. Proceedings of the Zoological Society 71 (1): 68-73. https://doi.org/10.1007/s12595-016-0183-x

Bona F.V. 1994. Family Dilepididae Railliet \& Henry, 1909. In: Khalil L.F., Jones A. \& Bray R.A. (eds) Keys to the Cestode Parasites of Vertebrates: 443-554. CAB International, Wallingford, UK.

Burt D.R.R. 1940. New species of cestodes from Charadriiformes, Ardeiformes, and Pelecaniformes in Ceylon. Ceylon Journal of Science, Section B, Zoology and Geology 22: 1-63.

Caira J.N. \& Jensen K. (eds) 2017. Planetary Biodiversity Inventory (2008-2017): Tapeworms from the Vertebrate Bowels of the Earth. University of Kansas, Lawrence. Available from http://hdl.handle.net/1808/24421 [accessed 27 Feb. 2020].

Czaplinski B. \& Vaucher C. 1994. Family Hymenolepididae Ariola, 1899. In: Khalil L.F., Jones A. \& Bray R.A. (eds) Keys to the Cestode Parasites of Vertebrates: 595-663. CAB International, Wallingford, UK.

Deardorff T.L., Schmidt G.D. \& Kuntz R.E. 1976. Tapeworms from Philippine birds, with three new species of Raillietina (Raillietina). Journal of Helminthology 50 (2): 133-142.

https://doi.org/10.1017/s0022149x00027619 
Dimitrova Y.D., Mariaux J. \& Georgiev B.B. 2013. Pseudangularia gonzalezi n. sp. and Gibsonilepis swifti (Singh, 1952) n. g., n. comb. (Cestoda, Dilepididae) from the House Swift, Apus affinis (J.E. Gray) (Aves, Apodiformes) from Franceville, Republic of Gabon. Systematic Parasitology 86 (3): 215-233. https://doi.org/10.1007/s11230-013-9445-4

Dimitrova Y.D., Mariaux J. \& Georgiev B.B. 2017. Redescriptions of four Palaeotropical species of the cestode genus Notopentorchis Burt, 1938 (Cyclophyllidea: Paruterinidae). Zootaxa 4290 (1): 61-82. https://doi.org/10.11646/zootaxa.4290.1.3

Dimitrova Y.D., Mariaux J., Georgiev B.B. \& Vasileva G.P. 2019. Two new cestode species of the family Hymenolepididae Perrier, 1897 (Cyclophyllidea) from passerine birds in Ethiopia, with the erection of Citrilolepis n. g. Systematic Parasitology 96: 279-297. https://doi.org/10.1007/s11230-019-09846-y

Fuhrmann O. 1932. Les Ténias des Oiseaux. Mémoires de l'Université de Neuchâtel 8: 1-382.

Fuhrmann O. \& Baer J.G. 1943. Mission biologique Sagan-Omo (Ethiopie méridionale), 1939, dirigée par le professeur Eduardo Zavattari. Cestodes. Bulletin de la Société neuchâteloise des Sciences naturelles 68: 113-140.

Galkin A.K. 1981. Cestodes from passeriform birds in the Kurish Spit. Trudy Zoologicheskogo Instituta Akademii Nauk SSSR 108: 53-98. [In Russian]

Georgiev B.B. \& Genov T. 1993. Ptilotolepis raymondi (Gigon et Beuret, 1991) comb. n. (Cyclophyllidea, Dilepididae): new geographical record and synonymy. Acta Parasitologica 38 (3): 119-123.

Georgiev B.B. \& Kornyushin V.V. 1994. Family Paruterinidae Fuhrmann, 1907 (sensu lato). In: Khalil L.F., Jones A. \& Bray R.A. (eds) Keys to the Cestode Parasites of Vertebrates: 559-584. CAB International, Wallingford, UK.

Georgiev B.B. \& Mariaux J. 2007. Cestodes of the genus Biuterina Fuhrmann, 1902 (Cyclophyllidea: Paruterinidae) from passeriform and piciform birds in the Ivory Coast, with a key to the species of the genus. Revue suisse de Zoologie 114 (1): 141-174. https://doi.org/10.5962/bhl.part.80392

Gigon P. \& Beuret J. 1991. Contribution à la connaissance des helminthes d'oiseaux dans le nord-ouest de la Suisse. Revue suisse de Zoologie 98 (2): 279-302. https://doi.org/10.5962/bhl.part.79792

Heneberg P., Georgiev B.B., Sitko J. \& Literák I. 2019. Massive infection of a song thrush by Mesocestoides sp. (Cestoda) tetrathyridia that genetically match acephalic metacestodes causing lethal peritoneal larval cestodiasis in domesticated mammals. Parasites and Vectors 12: e230.

https://doi.org/10.1186/s13071-019-3480-1

Illescas Gómez M.P. \& Gómez García V. 1984. Aportaciones al conocimiento de Variolepis farciminosa (Goeze, 1782) Spasskii y Spasskaya, 1954 (Cestoda: Hymenolepididae). Primera cita en España. Revista ibérica de Parasitología 44: 53-58.

Ivanova K., Zehtindjiev P., Mariaux J. \& Georgiev B.B. 2015. Genetic diversity of avian haemosporidians in Malaysia: Cytochrome b lineages of the genera Plasmodium and Haemoproteus (Haemosporida) from Selangor. Infection, Genetics and Evolution 31: 33-39. https://doi.org/10.1016/j.meegid.2015.01.004

Johri L.N. 1935. On Cestodes from Burma. Parasitology 27: 476-479.

https://doi.org/10.1017/s0031182000015407

Johri L.N. 1951. On avian cestodes of the family Dilepididae Fuhrmann, 1907, collected in Burma. Parasitology 41: 11-14. https://doi.org/10.1017/s0031182000016528

Joyeux C., Gendre E. \& Baer J.G. 1928. Recherches sur les helminthes de l'Afrique Occidentale Française. Collection de la Société de Pathologie Exotique Monographie II: 1-120. 
Kornyushin V.V. 1972. Cestodes from birds from the Northern Black Sea coast. In: Markevich A.P. (ed.) Problemy Parazitologii, Vol. 1. Naukova Dumka, Kiev [In Russian]

Kornyushin V.V. 1989. Fauna of Ukraine. Volume 33. Monogeneans and Cestodes. Issue 3. Davaineoidea. Biuterinoidea. Paruterinoidea. Naukova Dumka, Kiev. [In Russian]

Krabbe H. 1869. Bidrag til kundskab om fuglenes baendelorme. Videnskabernes Selskabs Skrifter, 5. rakke, Naturvidenskabelig og Mathematisk Afdeling 8: 251-389.

https://www.biodiversitylibrary.org/page/13596726

Krefft G. 1873. On Australian Entozoa, with descriptions of new species. Transactions of the Entomological Society of New South Wales 2: 206-232.

Kuntz R.E. 1969. Vertebrates taken for prasitological studies by U.S. naval medical research unit No. 2 expedition to North Borneo (Malaysia). Quarterly Journal of the Taiwan Museum 22: 191-206.

Lee C.C., Kawitha-Devi B. \& Amin-Babjee S.M. 1998. Parasites of bird (Columbiformes) in Peninsular Malaysia. Tropical Biomedicine 15: 29-36.

Lepage D. 2019. Avibase - the world bird database. Available from http://avibase.bsc-eoc.org [accessed 11 Nov. 2019].

Literák I., Olson P.D., Georgiev B.B. \& Špakulová M. 2004. First record of metacestodes of Mesocestoides sp. in the common starling (Sturnus vulgaris) in Europe, with an 18S rDNA characterisation of the isolate. Folia Parasitologica 51: 45-49. https://doi.org/10.14411/fp.2004.006

Mahon J. 1958. Helminth parasites of reptiles, birds, and mammals of Egypt: V. Avian Cestodes. Canadian Journal of Zoology 36 (4): 577-605. https://doi.org/10.1139/z58-054

Mariaux J. 1991. Cestodes of birds from the Ivory Coast. Species of the genus Anonchotaenia Cohn, 1900. Systematic Parasitology 20: 109-120. https://doi.org/10.1007/bf00007387

Mariaux J. \& Georgiev B.B. 2018a. Bird cestodes from Huinay (Comau Fjord), Chilean Patagonia: several species of the family Dilepididae (Platyhelminthes, Cyclophyllidea), with the erection of two new genera. ZooKeys 797: 1-18. https://doi.org/10.3897/zookeys.797.28005

Mariaux J. \& Georgiev B.B. 2018b. Seven new species of cestode parasites(Neodermata, Platyhelminthes) from Australian birds. European Journal of Taxonomy 440: 1-42. https://doi.org/10.5852/ejt.2018.440

Mariaux J. \& Vaucher C. 1988. Pseudochonanotaenia eburnea n. sp. (Cestoda: Cyclophyllidea) parasite de cinq espèces de Cisticola (Aves: Passeriformes) en République de Côte-d'Ivoire. Revue suisse de Zoologie 95: 249-256. https://doi.org/10.5962/bhl.part.79650

Mariaux J., Tkach V.V., Vasileva G.P., Waeschenbach A., Beveridge I., Dimitrova Y.D., Haukisalmi V., Greiman S.E., Littlewood D.T.J., Makarikov A.A., Philips A.J., Razafiarisolo T., Widmer V. \& Georgiev B.B. 2017. Cyclophyllidea van Beneden in Braun, 1900. In: Caira J.N. \& Jensen K. (eds) Planetary Biodiversity Inventory (2008-2017): Tapeworms from the Vertebrate Bowels of the Earth: 77-148. University of Kansas, Lawrence.

Matevosyan E.M. 1963. Dilepidoidea - Tapeworms of Domestic and Wild Animals. Izdatel'stvo Akademii Nauk SSSR, Moscow. [In Russian]

Matevosyan E.M. 1969. Paruterinoidea. Cestodes of domestic and wild birds. In: Skrjabin K.I. (ed.) Principles of Cestodology. Volume 7. Izdatel'stvo Akadamii Nauk SSSR, Moscow. [In Russian]

Mayhew R.L. 1925. Studies on the avian species of the cestode family Hymenolepididae. Illinois Biological Monographs 10: 1-126. https://doi.org/10.5962/bhl.title.50235 
Meggitt F.J. 1927. On Cestodes collected in Burma. Parasitology 19: 141-153.

https://doi.org/10.1017/s0031182000005606

Meggitt F.J. 1931. On Cestodes Collected in Burma. Part II. Parasitology 23: 250-263.

https://doi.org/10.1017/s0031182000013615

Moghe M.A. 1925. Two new cestodes from Indian Columbidae. Records of the Indian Museum 27: 431-437.

Movsessian S.O. 2003a. Davaineata - Tapeworms of animals and man. Part One. In: Beer S.A. (ed.) Foundation of Cestodology. Nauka, Moscow. [In Russian]

Movsessian S.O. 2003b. Davaineata - Tapeworms of animals and man. Part Two. In: Beer S.A. (ed.) Foundation of Cestodology. Nauka, Moscow. [In Russian]

Mutafchiev Y., Mariaux J. \& Georgiev B.B. 2014. Two new species of Quasithelazia Maplestone, 1932 (Nematoda: Acuariidae) from Malaysia, with an amended diagnosis and review of the genus. Systematic Parasitology 88: 103-117. https://doi.org/10.1007/s11230-014-9483-6

Okulewicz J. 1991. Ptilotolepis philomelae sp. n. (Cyclophyllidea, Dilepididae) - a new parasite of Turdus philomelos Brehm. Acta Parasitologica Polonica 36: 75-78.

Phillips A.J., Georgiev B.B., Waeschenbach A. \& Mariaux J. 2014. Two new and two redescribed species of Anonchotaenia (Cestoda: Paruterinidae) from South American birds. Folia Parasitologica 61 (5): 441-461. https://doi.org/10.14411/fp.2014.058

Ryšavý B. 1979. Anomotaenia skrjabiniana Spasskaya, 1958 (Cestoda: Dilepididae) in Czechoslovakia. Folia Parasitologica 26: 72.

Salamatin R.V. 1999. New cestode species from terrestrial birds from the fauna of Ukraine. Vestnik zoologii 33: 100.

Sawada I. \& Kugi G. 1979. Studies on the helminth fauna of Kyushu. Annotationes Zoologicae Japonenses 52: 133-141.

Schmidt G.D. 1986. CRC Handbook of Tapeworm Identification. CRC Press Inc., Boca Raton, Florida.

Scholz T., de Chambrier A., Kuchta R., Littlewood D.T.J. \& Waeschenbach A. 2013. Macrobothriotaenia ficta (Cestoda: Proteocephalidea), a parasite of sunbeam snake (Xenopeltis unicolor): example of convergent evolution. Zootaxa 3640: 485-499. https://doi.org/10.11646/zootaxa.3640.3.12

Schwendinger P.J. 2019. Volker Mahnert 3 December 1943 - 23 November 2018. Revue suisse de Zoologie 126: 1-16. https://doi.org/10.5281/zenodo.2619510

Shumilo R.P. \& Spasskaya L.P. 1975. Cestodes from Turdidae in Moldova. Parazity Zhivotnykh $i$ Rastenii 11: 53-73. [In Russian]

Singh K.P. 1959. Some avian cestodes from India: I. Species belonging to families Davaineidae and Biuterinidae. Indian Journal of Helminthology 11: 1-24.

Singh K.I., Krishnasamy M. \& Ming H.T. 1987. Collection of small vertebrates and their endoparasites from Ulu Endau Johore Malaysia. Malayan Nature Journal 41: 349-356.

Skrjabin K.I. \& Matevosyan E.M. 1945. Tapeworms - Hymenolepididae-from domesticated and game birds. Sel'khozgiz, Moscow. [In Russian]

Sodhi N.S., Koh L.P., Clements R., Wanger T.C., Hill J.K., Hamer K.C., Clough Y., Tscharntke T., Posa M.R.C. \& Lee T.M. 2010. Conserving Southeast Asian forest biodiversity in human-modified landscapes. Biological Conservation 143: 2375-2384. https://doi.org/10.1016/j.biocon.2009.12.029 
Soh M.C.K., Sodhi N.S. \& Lim S.L.H. 2006. High sensitivity of montane bird communities to habitat disturbance in Peninsular Malaysia. Biological Conservation 129: 149-166.

https://doi.org/10.1016/j.biocon.2005.10.030

Spasskaya L.P. 1957. On the fauna of cestodes from birds in Yakutia. II. Acta Veterinaria Academiae Scientiarum Hungaricae 7 (2): 101-127. [In Russian]

Spasskaya L.P. 1958. Two new species of cestode from birds in Tuva. Papers on Helminthology presented to Academician K.I. Skrjabin on his 80 th birthday: 349-353. Izdatel'stvo Akademii Nauk SSSR, Moscow, Russia.

Spasskaya L.P. 1966. Cestodes of birds of the USSR. Hymenolepididae. Nauka, Moscow. [In Russian]

Spasskaya L.P. \& Spasskii A.A. 1971. Cestodes of Birds in Tuva. Shtiintsa, Kishinev. [In Russian]

Spasskaya L.P. \& Spasskii A.A. 1977. Cestodes of Birds in the USSR. Dilepididae of Terrestrial Bird. Izdate'stvo Nauka, Moscow. [In Russian]

Tandan B.K. \& Singh K.S. 1964. Ophryocotyloides dasi sp. n. (Cestoda: Davaineidae) from a Himalayan barbet. Zoologischer Anzeiger 173: 441-443.

von Linstow O.F.B. 1879. Helminthologische Untersuchungen. Jahreshefte des Vereins für vaterländische Naturkunde in Württemberg 35: 313-342.

Widmer V.C., Georgiev B.B. \& Mariaux J. 2013. A new genus of the family Hymenolepididae (Cestoda) from Sephanoides sephaniodes (Apodiformes, Trochilidae) in Northern Patagonia (Chile). Acta Parasitologica 58 (1): 105-111. https://doi.org/10.2478/s11686-013-0117-y

Yamaguti S. 1959. Systema Helminthum. Vol. II. The Cestodes of Vertebrates. Interscience Publishers Inc., New York.

Yamaguti S. \& Mitunaga Y. 1943. Cestodes of birds from Formosa, I. Transactions of the Natural History Society of Taiwan 33: 268-277.

Manuscript received: 23 October 2019

Manuscript accepted: 16 December 2019

Published on: 16 March 2020

Topic editor: Rudy Jocqué

Desk editor: Pepe Fernández

Printed versions of all papers are also deposited in the libraries of the institutes that are members of the EJT consortium: Muséum national d'histoire naturelle, Paris, France; Meise Botanic Garden, Belgium; Royal Museum for Central Africa, Tervuren, Belgium; Royal Belgian Institute of Natural Sciences, Brussels, Belgium; Natural History Museum of Denmark, Copenhagen, Denmark; Naturalis Biodiversity Center, Leiden, the Netherlands; Museo Nacional de Ciencias Naturales-CSIC, Madrid, Spain; Real Jardín Botánico de Madrid CSIC, Spain; Zoological Research Museum Alexander Koenig, Bonn, Germany; National Museum, Prague, Czech Republic. 